\title{
Eğlence ve Yeme-içme İşletmelerinin Turizm Faaliyetlerine Yönelik Görüş ve Algılamalarının Belirlenmesi Üzerine Bir Araştırma: Boğaziçi Alanı Örneği
}

\author{
An Investigation to Determine Opinions and Perceptions of \\ Entertainment and Food \& Beverage Businesses towards \\ Tourism Activities: The Case of Bosphorus, Istanbul
}

\author{
(1) Aslı Altanlar, ${ }^{1}$ (1) Zeynep Enlil ${ }^{2}$ \\ ${ }^{1}$ Amasya Üniversitesi Mimarlık Fakültesi, Şehir ve Bölge Planlama Bölümü, Amasya

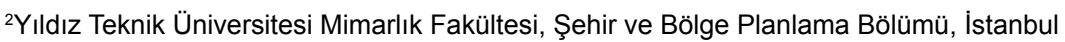

\section{ÖZ}

Bu çalışma, turizm odaklı bir gelişim senaryosunda turizmden herhang bir fayda sağlayamayacak kadar karar verme sürecinden soyutlanabilen yerel işletmelerin turizm gelişmesine yönelik tavır ve tutumlarını görünür kılmayı hedeflemektedir. Bu amaçla İstanbul'un önemli doğal ve kültürel kaynaklarından biri olan Boğaziçi Bölgesi'ndeki eğlence, yiyecek ve içecek hizmeti veren yerel işletmelere anket uygulanmıştır. Araştırmanın evrenini Boğaziçi Bölgesi'nde soyut ve somut kültürel mirası ve doğal mirası ile ön plana çıkan 26 mahalledeki işletmeler oluşturmuştur. İşletmelerin turizm müdahalelerine karşı davranış ve tutumlarını ölçebilmek için elde edilen veriler Temel Bileşenler Analizini (TBA), "Ağırlıklandırıımış Doğrusal Kombinasyon Yöntemi (WCL)" kullanılarak analiz edilmiştir. Bu analizler sonucu, yerel işletmelerin turizm odaklı davranış ve tutumlarını belirleyen yedi adet faktör belirlenmiştir. Bu faktörler "turizm odaklı stratejiler", "turizmin algılanan olumlu etkileri”, "rekabetçi çevre koşulları", "sosyo- ekonomik çevre koşulları", "yere bağılık", "sosyo kültürel çevre koşulları", turizmin algılanan olumsuz etkileri” olarak adlandırımıştır. Yerel işletmelerin turizme karşı davranış ve tutumlarını belirleyen en önemli faktörün "turizm odaklı stratejiler" olduğu görülmüştür. Sonuç olarak yerli ve yabancı girişimcileri kente çekmek üzere yapılan müdahalelerin mahalledeki sosyo-ekonomik ve fiziki dokusunda bir değişim meydana getireceği ve bu değişimin mahallenin özgün kimliğinin de değişmesine ve hatta hem mahalle sakinlerinin hem de yerel işletmelerin giderek yerlerinden edilmelerine neden olan bir soylulaşma sürecini tetikleyeceği unutulmamalıdır. Bu ise kent hakkı ve yerel kimlikle ilgili pek çok problemi de beraberinde getirecektir. Bu çalışma, sürdürülebilir ve adaletli bir kentsel gelişme için yerel halkı ve yere özgü değerleri gözeten kamu politikalarına ihtiyaç olduğunu ortaya koymaktadır.

Anahtar sözcükler: Boğaziçi bölgesi; turizmin etkileri; turizm odaklı müdahaleler; yerel işletmeler.

\section{ABSTRACT}

This study, therefore, aims at revealing reactions and attitudes towards tourism, of local enterprises, which are excluded from the decision-making process to the extent that they can get no benefits in a tourism-oriented development scenario. To that end, a questionnaire conducted on local food-beverage and accommodation enterprises at Bosporus Site, which is a significant natural and cultural asset of Istanbul. Population of the research consist enterprises at 26 neighborhoods, which stand out with their cultural and natural heritage. In order to measure reactions and attitudes of enterprises to tourism interventions, obtained data was analyzed through "Principal Components Analysis (PCA)", "The Weighted Linear Combination Method (WCL)". Seven factors as determinants of local enterprises' reactions and attitudes towards tourism were concluded from the analysis. Those factors were respectively named "tourism- oriented interventions," "positive influences of tourism", "competitive environmental conditions", "socio -economic environment perception", place attachment", "socio-cultural environment perception," and "negative influences of tourism." It was found that "tourism- oriented interventions" is the factor most determining local enterprises' reactions and attitudes towards tourism. To conclude, it should be remembered that interventions made in order to attract local and foreign entrepreneurs to the city will change the socio-economic and physical texture of the neighborhood, and such a change, in turn will trigger a gentrification process which will also change authenticity of the neighborhood and will even pave the way for the gradual displacement of both inhabitants and local enterprises. That will bring along many problems regarding the right to the city and local identity. This study shows that public policies safeguarding local people and indigenous values are required for a sustainable and fair city development.

Keywords: Bosporus bite; influences of tourism; tourism oriented interventions; local enterprises.

Geliş tarihi: 17.09.2018 Kabul tarihi: 20.10.2019

Online yayımlanma tarihi: 14.02 .2020

İletişim: Aslı Altanlar.

e-posta: asli.altanlar@gmail.com 


\section{Giriş}

Kentsel endüstrinin zayıflamasıyla birlikte, sanayinin kent merkezinden desantralizasyonun bir sonucu olarak, kentlerde gelir dağılımlarına, fırsatlara ve yaşam biçimlerine göre kutuplaşmalar ortaya çıkmıştır. Kentte meydana gelen bu değişim, hizmetler sektörüne dayalı ekonomik büyümeyi de teşvik etmiştir. Ancak 1990'lı yıllara kadar hizmetler sektöründe bir büyüme söz konusu olmasına rağmen, hizmet sektöründeki istihdam olanakları, üretim sektöründeki kaybı karşılayamamıştır (Hall, 1998). Bu süreçte yerel yönetimler şehir merkezlerinin üretimde bir daha asla egemen olamayacağını düşünmeye başlamış ve 1980'li yıllardan itibaren içinde bulundukları bu durumdan çıkabilmek için yapabilecekleri en iyi şeyin, keskinleşen rekabet ortamında serbest hale gelen yatırım ve sermaye akışını kendilerine çekebilmek olduğunu düşünmeye başlamışlardır. Yerel idarelerin bu yaklaşımı asında neoliberal bir ideolojinin ve rekabetçi ve girişimci bir kent modelinin onaylanması ile paraleldir (Bolzoni, 2014, s. 13). Bu amaçla yerel yönetimler, turistlere alıştığı yaşam biçimi ve konfordan uzaklaşmadan, yeni mekanlar ve insanlar görüp 'seyretme' firsatı sağlamak amacıyla şehirlerin tarihsel geçmişini pazarlamaya yönelik yaklaşımları benimsemişlerdir (Öncü, 2005, s. 86; Huning \& Novy, 2006, s. 10). Mommaas (2004), bu durumu "şehirlerin, tarihi yapıların simgesel ve ekonomik potansiyellerinin kullanılması yönünde bir politikaya yönlendiğini” ifade ederek açıklamaktadır.

Bir bölge yada semtte turizmi geliştirmek için ilk akla gelen stratejilerden biri, canlı bir gece ekonomisinin varlığını sağlamaya çalışmaktır (Bolzoni, 2013; Grodach \& LoukaitouSideris, 2007; Hall, 1998). Bu nedenle, dinlence ve eğlence işletmelerinin açılması yerel makamlar tarafından teşvik edilmese de memnuniyetle karşılanabilmekte, ya da yan etkileri göz önünde bulundurulmamaktadır. Hatta zaman zaman yerel yönetimler kentin gece hayatını canlandıran eğlence mekanlarını artması için çeşitli müdahalelerde bulunabilmektedir (Bolzoni, 2014; Bolzoni, 2013; Grodach \& Loukaitou-Sideris, 2007; Hall, 1998). Ancak, gece ekonomisinin geliştirilmesi ile birlikte, mahallede iki tür girişimci söz konusu olmaktadır. Bunlardan ilki mahallenin sosyal ve kültürel gelişiminin bir parçası haline gelmiş ve bulundukları bölgeye karşı aidiyet hisseden küu̧ük ve orta ölçekli işletmeler, ikincisi de ağılıklı olarak değişen bir mahallede iyi bir yatırım yapmak için fırsat kollayan ve eğlence ekonomisinin uzmanları haline gelmiş olan ulusal ve uluslararası girişimcilerdir (Bolzoni, 2013, s. 19). İkinci tür girişimcilerin kentsel alana müdahaleleri ile kafe, restoran ve kulüpler gibi mekanlar gelir seviyesi yüksek olan kent sakinleri ile ziyaretçilerin tüketim alışkanlıklarının kurumsallaşması için bir araç haline gelebilmektedir (Bolzoni, 2013, s. 4). Bu durum çok uluslu şirketlerin, turizm hizmetleri sunan küçük ve orta ölçekli işletmeleri sömürmesine de yol açabilmektedir. Bu şekilde küçük ölçekli girişimciler zamanla piyasadan uzak- laştırılmakta ya da çekilmek zorunda bırakılmaktadır (Doğan, 2004, s. 146). Değişimin bu yöndeki olumsuz etkileri ile birlikte yere(le) özgü değerler ve alışkanlıkların yerini bu yeni uygulamalar ve kullanımlar almaya başlamaktadır. Bunun bir sonucu olarak meydana gelen kentsel değişimde bazı taraflar fayda sağlarken diğerlerinin dışlanması söz konusu olabilmektedir (Bolzoni, 20I3, s. 4; Huning \& Novy, 2006, s. 15). Çünkü bu tür yaklaşımlarda politikalar ve müdahaleler, kent kullanıcıları, turistler ve geçici sakinlere odaklanma eğilimindedir; bu arada diğer nüfus segmentleri göz ardı edebilmektedir (Bolzoni M., 2014 , s. II). Bunun sonucu olarak dışlanan taraf ise genellikle mahalle sakinleri ve yere(le) özgü küçük ve orta ölçekli işletmeler olmaktadır (Wilson \& Keil, 2008; Peck, 2005). Aslında, mahallelerin ve kentsel alanların dinlence ve tüketim yerleri olarak ortaya çıkması, genellikle ticari ve konutsal soylulaştırma, yer değiştirme sürecini ve kamusal kaynakların meşru tahsisi ve kamusal alan kullanımı ilgili pek çok problemi de beraberinde getirebilmekte ve paydaşlar arasında gerginlik ve çatışmalara neden olabilmektedir (Bolzoni, 20I4, s. II). Bu tür olumsuzlukların önüne geçilmesi ve turizmden sağlanan faydanın tüm paydaşlar açısından hissedilebilir hale getirilmesi için turizm odaklı stratejiler belirlenmeden önce bölgede yaşayan halkın ve faaliyet gösteren küçük ve orta ölçekli işletmecilerin turizm ile ilgili bilgi, beceri ve temaslarının tespit edilmesi ve eğer var ise turizm gelişmesine karşı olumsuz algı ve tutumlarının nedenlerinin araştırılması ve fikirlerinin mutlaka alınması gerekmektedir. Ancak bu şekilde turizmin geliştirilmesi adına yapılan müdahalelerin sürdürülebilir olmasından bahsedilebilir. Başka bir ifadeyle turistlerin olduğu kadar ağırlayan bölgenin güncel ihtiyaçlarını yerine getiren, temel ekolojik süreçleri ve kültürel bütünlüğü dikkate alan, ekonomik sürekliliği, toplumsal ve yerel refahı iyileştirmeyi ve sosyal eşitliği sağlamayı hedefleyen, çevresel ihtiyaçlar ile birlikte tüm kaynakların korunması ve yönetimini bütünleştiren bir turizm anlayışı benimsenmelidir. Bu hedefler doğrultusunda turizm türü, büyüklüğü ve gelişimi ile ilgili politikalar belirlemeden önce bölge için önerilen turizm stratejisinin ne kadar doğru olduğu, hedeflere ne kadar yaklaştı̆̆ı, hedeflere ulaşmadaki engellerin tanımlanması ve gidirilmesi için ne gibi çalışmalar yapılması gerektiği, turistik gelişmenin etkilerinin neler olacağı konusunda ayrıntılı bilgi edinilmesi gerekmektedir. Bu bilginin edinilebilmesi için öncelikle turizm planlamasında turistik tüketime ayrılan alanların belirlenmesinde aktif olarak rol alan tarafların incelenmesi gerekmektedir. Bu taraflar yerin sakinleri, girişimciler ve merkezi ve yerel yönetimlerdir. Bir yerde gerçekleşen turizm faaliyetleri sadece o yerin sakinlerini etkilememekte aynı zamanda bu özel alanı kullananları, turistleri ve çalışanları da etkilemektedir. Ancak turistler ve o bölgede çalışanlar problemin tanımlanmasında ya da fikir birliğinin sağlanmasında aktif olarak rol almamaktadırlar (Bolzoni, 2013, s. 17). Bu nedenle turizm planlamasında öncelikle yerin sakinleri, girişimciler ve merkezi ve yerel yönetimlerin eğilim ve beklentilerine odaklanılmalıdır. Bu bakış açısıyla, bir alanın 


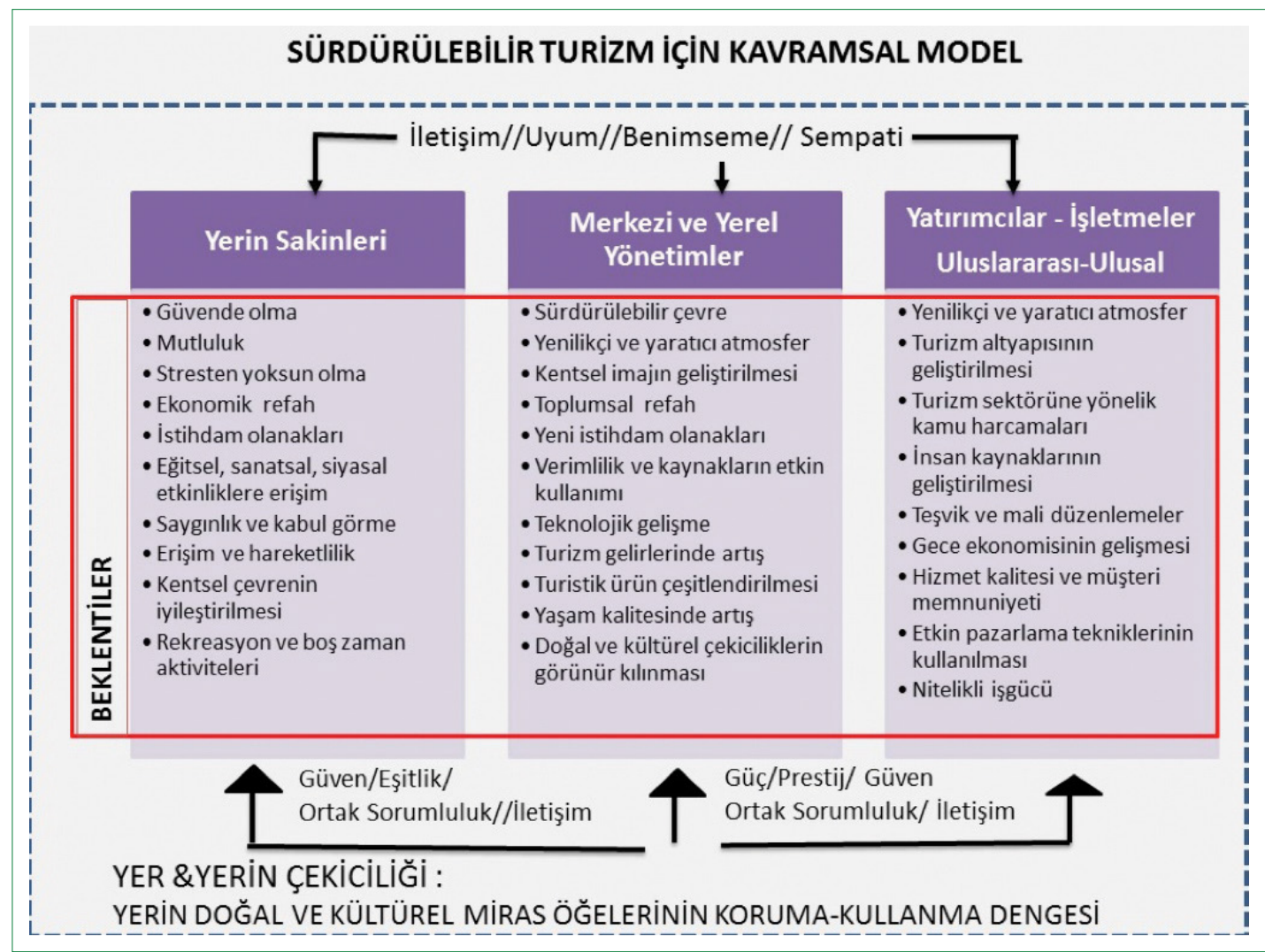

Şekil I. Sürdürülebilir turizm planlaması için kavramsal bir model.

turizm amaçlı planlanmasında beş temel aşamadan söz etmek mümkündür. Birinci aşamada turizmde aktif olarak yer alması gereken tüm kişi ve kurum ve kuruluşların analizinin yapılması gerekmektedir. İkinci aşamada planlama alanının turizm gelişmesi açısından temel sorun ve olanakları tespit edilmelidir. Üçüncü aşamada planlamaya geçmeden önce tespit edilen sorunlar önem sırasına göre sıralanmalıdır. Dördüncü aşamada ise seçenekler tartışılmalı ve çözümler tanımlanmalıdır. Son aşamada ise planlama stratejisi ortaya konulmalıdır (Kuntay, 2004 , s. 48-49). Anlaşıldığı üzere sürdürülebilir turizm planlamasını planın yapılacağı yer ve o yerin dinamiklerini oluşturan karar vericiler, girişimciler ve yerin sakinlerinden bağımsız düşünmek mümkün değildir. Çünkü turizmle etkileşim içinde olan paydaşların yer ve birbirleri ile olan ilişkilerinin ve zamana bağlı olarak çıkması olası değişmelerin çözümlenmesi planlamanın en öncelikli amaçları arasında yer almaktadır (Şekil I). Bu nedenle turizm planlamasında turizmin; yer, yerin sakinleri, yerel idareciler ve girişimcilerin hangi özelliklerinden etkilendiğini ve bu özellikleri arasındaki ilişkileri tanımlayan çok boyutlu bir araştırma yöntemine ihtiyaç duyulmaktadır.

Buraya kadar aktarılan meselelerden anlaşıldığı üzere bu çaIışma, turizm planlamasında turistik tüketime ayrılan alanların belirlenmesinde aktif olarak rol alması gereken eğlence ve yeme-içme işletmelerinin turizm gelişmesine dair algı ve tutumlarına odaklanmaktadır. Bu nedenle, öncelikle Boğaziçi öngörünüm alanındaki mahallelerde yer alan eğlence, yeme içme ve dinlence işletmelerinin turizmin gelişmesinden nasıl etkilendiklerini ve turizm gelişmesine karşı davranış ve tutumlarını belirleyen faktörlerin neler olduğu ve bu faktörlerin turizm gelişmesine karşı bakış açılarını ne düzeyde etkilediği sorularına yanıt aranmaktadır. İkinci olarak söz konusu etkiler konusunda eğlence ve yeme içme işletmelerinin ikilemleri ve endişelerinin neler olduğu keşfedilmeye çalışılmaktadır.

\section{Materyal ve Yöntem}

\section{I. Araştırmanın Kapsamı ve Sınırlılıkları}

Ritchie ve Crouch (2000, s. 2)'a göre bir destinasyonun seçimini ve turist ziyaretini etkileyen en önemli etmenler o yerin fiziksel, beşeri, tarihi, kültürel, bilgi ve sermaye kaynakları ile turizm alt ve üst yapısını oluşturan kaynaklardır. Bu kaynakların uzun dönemde etkili ve verimli kullanımı da turizmin sürdürülebilirliğini sağlamaktadır. Turizm kaynaklarını, bir şehri ziyaret etmeye karar verme aşamasındaki önem derecelerine göre temel kaynaklar, ikincil kaynaklar ve ek kaynaklar olmak üzere üç sınıfa ayırmak mümkündür (Tablo I). İkincil kaynakların birincil kaynaklara oranla turistleri turistik bir bölgeye doğru harekete geçirme etkileri daha azdır. Ancak bu kaynaklar kentin kullanıcıları ve bölge sakinlerinin gündelik yaşamlarını devam ettirmesi ve yaşayanların fiziksel, sosyal ve 
Tablo I. Turizmin kaynakları

\begin{tabular}{|c|c|}
\hline \multicolumn{2}{|c|}{ Temel kaynaklar } \\
\hline Doğal kaynaklar & Kültürel tesisler \\
\hline Bozulmamış doğal alanlar & Müzeler ve Sanat Galerileri \\
\hline Milli parklar (milli parklar, tabiat anıtları -tabiat parkları gibi) & Tiyatrolar ve Sinemalar \\
\hline Doğal sit alanları (II-III derecede doğal sit alanları) & Konser Salonları \\
\hline Fiziksel karakteristikler & Kongre Merkezleri \\
\hline Arkeolojik ve kentsel sit alanları & Diğer ziyaretçi çekicilikleri \\
\hline Geleneksel mimari & Spor tesisleri \\
\hline Tarihi sokak düzeni & Kapalı ve açık \\
\hline Eski uygarlık abideleri ve heykeller & Rekreasyon (eğlence-dinlence) işletmeleri \\
\hline Dini yapılar & Gece kulüpleri \\
\hline Su yapıları & Gazinolar ve bingo kulüpleri \\
\hline İlginç yapılar & Disko ve dans barlar \\
\hline Parklar ve yeşil alanlar & Özel etkinlikler \\
\hline Sosyo-kültürel değerler & Festivaller \\
\hline \multicolumn{2}{|l|}{ Mekanların canlılığı } \\
\hline \multicolumn{2}{|l|}{ Dil (tercümansız konuşabilme olanakları ve arkadaşlık) } \\
\hline \multicolumn{2}{|l|}{ Yerel gelenek ve kostümler } \\
\hline \multicolumn{2}{|l|}{ Kültürel miras } \\
\hline \multicolumn{2}{|l|}{ Hoşgörü ve misafirperverlik } \\
\hline \multicolumn{2}{|l|}{ Güvenlik } \\
\hline İkincil kaynaklar & Ek kaynaklar \\
\hline Konaklama çeşitleri & Erişilebilirlik \\
\hline Mutfak kültürü & Ulaşım ve teknik altyapı \\
\hline Yiyecek-içecek tesisleri & Kentsel peyzaj, rekreasyon ve yeşil açık alanlar \\
\hline Ticaret, alış-veriş olanakları & Turist danışma (haritalar, işaretler, rehberler) \\
\hline \multicolumn{2}{|l|}{ Geleneksel pazarlar (kapalı çarşı gibi) } \\
\hline Müzayede salonları & \\
\hline
\end{tabular}

Christoppher, 2002; Kuntay O., 2004, s. 86; Özer, 2010, s. 17; Dwyer \& Kim, 2003, s. 400-405 uyarlanarak.

kültürel çevreleri ile kurdukları bağı güçlendirmesi nedeniyle turizm planlaması açısından önemlidir. İkincil kaynaklar ve ek kaynakların kalitesi aynı zamanda yaşayanların ve kentin kullanıcılarının yaşam kalitesini de belirlemektedir (Bahar, 2004, s. 45-49; Dwyer \& Kim, 2003, s. 400-405). Bu nedenle bu çalışmada aynı zamanda yaşayanların ve kentin kullanıcılarının boş zaman aktivitelerini gerçekleştirmelerine olanak tanıyan eğlence-dinlence işletmeleri ile yeme-içme işletmeleri üzerine odaklanılmaktadır. Bu odak çerçevesinde öncelikle turizm sektöründe hizmet veren eğlence ve yiyecek içecek işletmelerinin Boğaziçi Bölgesi'ndeki sosyal, kültürel, fiziksel, ekonomik çevre faktörleri ve yasal ve hukuki düzenlemeler ile ilgili koşulları nasıl değerlendirdiklerini anlayabilmek amaçlanmaktadır. İkinci olarak işletmelerin turizm gelişmesine karşı algı ve tutumlarını belirleyen faktörler ortaya konulmaktadır. Üçüncü olarak işletmelerin turizm gelişmesine karşı algı ve tutumlarının mekansal olarak nasıl farklılaştı̆̆ı ortaya konulmaktadır. Son olarak elde edilen veriler çerçevesinde sorunlar ve çözüm önerileri ortaya konulmaktadır.

\subsection{Materyal ve Yöntem}

Çalışma alanı olarak İstanbul Boğaziçi Bölgesi seçilmiştir. Boğaziçi Bölgesi, kentin tarihi kültürel kimliğini yansıtan ve tarihsel geçmişten gelerek günümüze ulaşan kentsel mekanlar, yapılar ve tarihi kent imajını yansıtan peyzaj değerleri ve tabiat varlıkları ile İstanbul'a sahip olduğu kimliğini kazandıran en önemli bileşenlerden biridir (ÇDP, 2009, s. 603). Bu özellikleri ile Boğaziçi Bölgesi'nin I/I00000 ölçekli Çevre Düzeni Planı'nda kültür, turizm ve rekreasyon kullanımları açısından potansiyel arz ettiği vurgulandığı görülmektedir (ÇDP, 2009, s. 576). Ancak bilindiği üzere bir bölgede turizm faaliyetlerinin geliştirilmesi ve turizm gelişiminin devam edebilmesi birçok faktöre bağlıdır. Turizm sektöründe yaşanan tüm gelişmeler turizmin söz konusu olduğu çevrede olumlu yada olumsuz yönde doğrudan karşılı̆ııı bulmaktadır. Bu nedenle sürdürülebilir turizm gelişmesini, sosyo-kültürel ve siyasi çevrenin fiziki mekana yansımasını da ifade eden yer ve o yerle sürekli etkileşim halinde olan yerin sakinleri ve girişimcilerden bağım- 


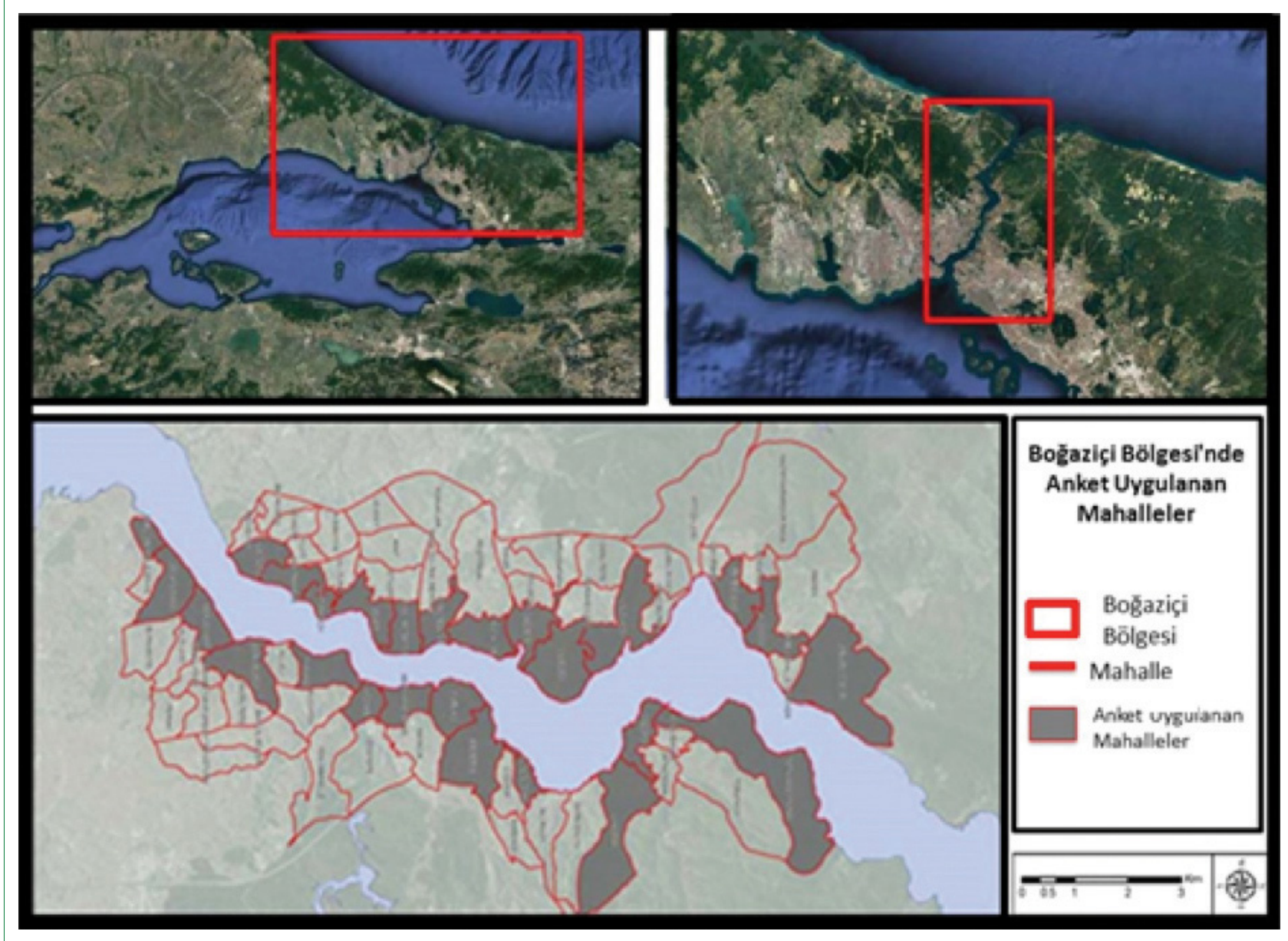

Şekil 2. Çalışma alanının konumu.

sız düşünmek mümkün değildir. Turizm gelişmesinin bu çok boyutlu yapısı gereği, turizm gelişmesinden doğrudan ve dolaylı olarak etkilenecek ve bu süreci etkileyebilecek olan paydaşların turizme karşı bakış açısı, turizm gelişmesini nasıl algıladığı, turizm gelişmesinden beklentisinin neler olduğu ve bu bağlamda turizm gelişmesinin yer(el) açısından ne tür fırsatlar ve tehditler içerdiğinin tespit edilmesi gerekmektedir. Bu şekilde farklı temsil ve uzmanlık alanlarındaki kentlilerin ihtiyaç ve önerilerini keşfederek kentin turizm gelişmesi açısından dimamiklerinin olumlu ve olumsuz yönlerini objektif bir şekilde ortaya koymak mümkün olabilir. Bu nedenle bu çalışma Boğaziçi Bölgesi'ndeki turizm gelişmesinden doğrudan ve dolaylı olarak etkilenecek ve bu süreci etkileyebilecek olan eğlencedinlence, yeme içme işletmelerinin bu tür bir gelişmeyi nasıl değerlendirdiklerini ortaya koymayı amaçlamaktadır. Ancak, çalışmanın zaman ve maliyet açısından kısıtlılıkları nedeniyle anket çalışması Boğaziçi Bölgesi'nin tamamında gerçekleştirilememiştir. Anketler sivil mimari örnekleri, arkeolojik buluntuları ve kıyı yerleşmeleri gibi özellikleri ile turizm odaklı gelişme açısından Boğaziçi Bölgesi'nde ön plana çıkan 26 adet mahalledeki eğlence-dinlence ve yiyecek ve içecek işletmelerine "sistematik örnekleme tekniği" ile uygulanmıştır (Şekil 2).
Çalışma alanında faaliyet gösteren işletmelerin sayısı Üsküdar, Beykoz, Sarıyer ve Beşiktaş ilçe belediyelerinin 'Ruhsat ve Denetim Müdürlükleri'nden alınan 2014 yılı verilerine göre belirlenmiştir (Üsküdar Belediyesi, 20I4; Beşiktaş Belediyesi, 2014; Sarıyer Belediyesi, 20I4; Beykoz Belediyesi, 20I4). 2014 yllı verilerine göre belirlenen eğlence, yeme içme işletmeleri 604 adet olup, \%95 güven aralığı ve 0,05 anlamlılık düzeyinde örneklem hacmi 236 olarak tespit edilmiştir (Tablo 2).

\subsection{Niceliksel ve Niteliksel Faktörlerin Ölçülmesi}

Literatürde turizm gelişmesini belirleyen niceliksel faktörler; insan sermayesi ve eğitim (yerel halk, turizm çalışanları ve turistler), bilişim teknolojileri ve teknolojik gelişme, turizmin arz koşulları (doğal, sosyal ve kültürel varlıklar, altyapı ve ulaşım gibi faktörler), maliyet, yatırım, teşvik ve mali düzenlemeler (Bahar, 2004, s. 67-72; Dwyer \& Kim, 2003, s. 5; Yoon Y., 2002, s. 31-35), niteliksel faktörler ise; turizmin talep koşulları (politik-yasal, psikolojik gibi faktörler), hizmet kalitesi ve müşteri memnuniyeti, verimlilik ve kaynakların etkin kullanımı, turistik ürün çeşitlendirmesi, imaj ve yenilik ve devlet ve bürokrasi olarak özetlenmektedir (Yoon Y., 2002, s. 
Tablo 2. Boğaziçi bölgesindeki eğlence, yiyecek içecek işletmelerinin örneklem büyüklüğünün mahallelere göre dağıımı

\begin{tabular}{|c|c|c|c|c|c|}
\hline \multirow[t]{2}{*}{ Mahalle adı } & \multicolumn{2}{|c|}{ Yerel işletmeler } & \multirow[t]{2}{*}{ Mahalle adı } & \multicolumn{2}{|c|}{ Yerel işletmeler } \\
\hline & $\begin{array}{l}\text { Yiyecek içecek } \\
\text { işletmeleri }\end{array}$ & Örnek dağılımı & & $\begin{array}{l}\text { Yiyecek içecek } \\
\text { işletmeleri }\end{array}$ & Örnek dağılımı \\
\hline Arnavutköy & 27 & 11 & Göksu & 5 & 2 \\
\hline Kuruçeşme & 22 & 9 & Anadolu Hisarı & 13 & 5 \\
\hline Ortaköy & 25 & 10 & Anadolu Kavağı & 20 & 8 \\
\hline Bebek & 21 & 8 & Yalıköy & 6 & 2 \\
\hline Tarabya & 28 & II & Paşabahçe & 19 & 7 \\
\hline Baltalimanı & 3 & I & Çubuklu & 20 & 10 \\
\hline Emirgan & 20 & 8 & Beykoz Merkez & 7 & 3 \\
\hline Rumeli Hisarı & 64 & 25 & Kanlıca & 12 & 5 \\
\hline Rumeli Kavağı & 17 & 7 & Beylerbeyi & 28 & 10 \\
\hline Yeniköy & 42 & 16 & Sultantepe & 22 & 9 \\
\hline Büyükdere & 22 & 9 & Kuzguncuk & 27 & 10 \\
\hline Merkez & 41 & 16 & Çengelköy & 37 & 13 \\
\hline İstinye & 44 & 17 & Kandilli & 12 & 4 \\
\hline Avrupa yakası toplam & 376 & 148 & Anadolu yakası toplam & 228 & 88 \\
\hline
\end{tabular}

3I-35; Andereck \& Nyaupane, 20I I, s. 253). Bu nedenle bu çalışmanın niceliksel boyutu iki temel başıkta ele alınmıştır. Turizmin arz koşulları (türü, faaliyet süresi, hukuki bakımdan belge türü, müşteri kapasitesi, mülkiyet durumu vb.) ve insan sermayesi (istihdam edilen personelin sayısı, eğitim durumu ve yabancı dil bilen personel sayısı).

Çalışmanın niteliksel boyutu ise turizm gelişiminin işletmeler tarafından nasıl algılandığı, işletmelerin çevresel koşulları nasıl değerlendirdiklerini ve bu koşullara dair memnuniyetlerini ortaya koymaktadır.

Turizm işletmelerinin turizm gelişmesi açısından yere özgü özellikleri nasıl değerlendirdiğini ortaya koymak amacıyla sorulan sorulara verilen cevapları skor cinsinden ifade edebilmek için Raphael ve diğerlerinin $(1998$, s. 5) ortaya koydukları "Yaşam kalitesi skoru $=[($ Önem düzeyi /3) $\mathrm{x}$ (Memnuniyet düzeyi - 3)]" formülünden yararlanılmıştır. Bu amaçla işletmelerin yere dair çevresel faktörleri nasıl algıladığını belirleyen sübjektif verileri skor cinsinden ifade edebilmek için; "Yerin algılanan kalitesi (YK)=[(Önem düzeyi /3) x (Yeterlilik düzeyi-3)]" formülü kullanılıştır. Hazırlanan anket formunda öncelikle turizm destinasyonunun gelişimini etkileyen ekonomik, fiziksel, tarihi ve kültürel çevre özelliklerine dair verilen her bir ifadelerin işletmeler için ne kadar önemli olduğu sorgulanmış, ikinci olarak işletmelerin söz konusu ifadeleri bulunduğu mahalle açısından değerlendirdiklerindeki memnuniyet düzeyleri sorgulanmıştır. Bu şekilde turizm işletmeleri açısından yerin algılanan kalitesi için -3.33 ve +3.33 arasında değişen skor değerleri elde edilmiştir (Tablo 3) (Raphael, ve diğerleri, 1998, s. 5; Andereck \& Nyaupane, 20II, s. 252).
Devlet ve bürokratik işlemler, turizm gelişmesini olumlu ya da olumsuz yönde etkileyebilmektedir. Bu nedenle anketin ikinci bölümünde işletmelerin, merkezi ve yerel yönetimlerin turizm gelişmesini etkileyecek hukuki yaptırım ve yasal düzenlemeler ile teşvikler, destekler ve pazarlama stratejileri konusunda ortaya koyduğu stratejileri nasıl değerlendirdiklerini ortaya koymak amacıyla verilen 18 ifadeyi önem ve memnuniyetleri açısından değerlendirmeleri istenmiştir. İşletmelerin turizm odaklı stratejiler (TS) ile ilgili yargılara verdikleri cevapları skor cinsinden ifade edebilmek için kullanılan "TS=[(Önem düzeyi /3) $x$ (Yeterlilik düzeyi-3)]" formülü ile her bir ifade için -3.33 ve +3.33 arasında değişen skor değerleri elde edilmiştir (Tablo 3).

Çalışmada bireylerin bir yere verdiği değerin ölçüsünü, bireyler ve yaşadıkları çevreler arasındaki güçlü çağrışımı, bireyin bir yere ilişkin fonksiyonel hisleri ile duygusal ya da sembolik çağrışımlarını ifade etmesi nedeniyle yere bağlılık boyutuna da yer verilmiştir. Çünkü bir yere kişinin kendi özlemleri ve deneyimleri ile bağlanması da o yerden alınacak memnuniyet seviyesini belirlemektedir (Yılmaz Çakmak, 2013, s. 55). Bu nedenle anketin üçüncü bölümünde işletmelerin yere dair sembolik çağrısımlarını ve yere dair genel memnuniyetlerini belirleyebilmek amacıyla 5 adet ifade verilmiş ve bu ifadeleri 5'li likert ölçeğine ( $I=$ =kesinlikle katılmıyorum'dan $5=$ kesinlikle katılıyorum'a doğru) göre cevaplamaları istenmiştir.

Anketin dördüncü bölümünde ise işletmelerin turizm gelişmesi ile ilgili genel yargılarını ortaya koyabilmek için 18 adet ifade verilmiş ve verilen ifadeleri $5^{\prime} l i$ likert ölçeğine göre yanıtlamaları istenmiştir. Her iki boyutu oluşturan yargılara verilen cevapları skor cinsinden ifade edebilmek için ise; ilk olarak, olumlu yargı içeren her bir değişkene verilen cevaplar 


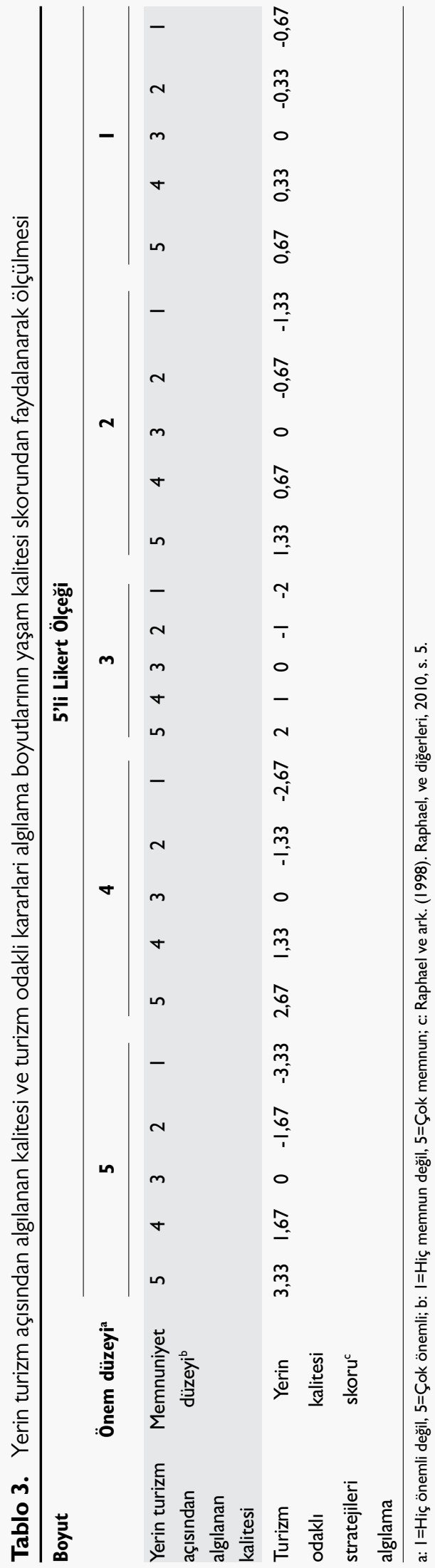

(5'li likert ölçeği; I=kesinlikle katılmıyorum'dan 5= kesinlikle katıllyorum'a doğru) için l'in -3'e, 2'nin -2'ye, 3'ün l'e, 4'ün 2'ye ve 5'in 3'e eşit olacağı şekilde yeniden kodlandırılmıştır. Olumsuz ifadelere verilen cevaplar ise l'in +3 , 2'nin +2 'ye 3'ün l'e 4'ün -2'ye, 5'in -3'e eşit olacağı şekilde yeniden kodlanarak skor cinsinden ifade edilmiştir (Tablo 4) (Andereck \& Nyaupane, 20II, s. 252).

Tüm yargılara verilen cevaplar skor cinsinden ifade edildikten sonra örneklem büyüklüğünün faktörleşmeye uygunluğunu test etmek amaciyla Kaiser-Meyer-Olkin (KMO) testi uygulanmıştır (Çokluk, Şekercioğlu, \& Büyüköztürk, 20I0, s. 207). Örneklem sayısının sağlıklı bir değerlendirme yapmak için yeterli olduğu sonucuna varılmasından sonra ölçeğin boyutlarının belirlenmesi amacıyla temel bileşenler analizi (PCA) yapılmışır. PCA işleminde varimax dönüştürme yöntemi kullanılmıştır. PCA işlemi değişkenler faktör yük değerleri faktör yükü $\geq 0,400$ ve $\mathrm{F} 2-\mathrm{FI}=0,100$ olarak kabul edilmiştir. Son olarak işletmelerin turizm gelişmesine verdikleri desteğin mekansal dağııııını ortaya koyabilmek için "Çok Ölçütlü Değerlendirme Yöntemi (WCL)" uygulanmıştır (Şekil 3).

\section{Bulgular}

\section{I. Boğaziçi Alanı'ndaki Eğlence, Yiyecek İçecek İşletmelerinin Betimlemesi}

Turizm altyapısını oluşturan eğlence, yeme-içme işletmelerinin turizm açısından önemli olan niceliksel özelliklerini ortaya koyabilmek için anket formunda işletme türü, hukuki yapısı, müşteri kapasitesi, bilgi ve iletişim teknolojilerini kullanımı, personel sayısı ve personelin eğitim düzeyi gibi özellikleri sorgulanmıştır. Elde edilen bulgulara göre eğlence yeme ve içme işletmeleri ile yapılan görüşmelerin \%23,7'si firma sahipleri, \%3'ü firma ortağı, \%45,3'ü üst düzey yönetici ve \%28'i ise işletmede çalışan şefler ile gerçekleştirilmiştir. İşletmelerin $\% 16$, I'i 1933 ve 1992 yılları arasında, \%55, l'i 2003-2012 yılları arasında, \%9,3'ünün ise 2013 yılından itibaren hizmet verdiği tespit edilmektedir. Elde edilen bulgular işletmelerin uzun yıllardır bölgede faaliyetlerine devam etiklerini göstermektedir. Boğaziçi Bölgesi'ndeki eğlence, yeme içme işletmelerinin \%78,9'unun mikro işletmeler ( 10 kişiden az çalş̧anlı) olduğu, \%2I, I'inin küçük ölçekli işletmeler ( 10 ve/veya 50 kişiden az çalışanlı) olduğu tespit edilmektedir. Boğaziçi Bölgesi'ndeki eğlence, yeme içme işletmelerinde çalışan iş̧̧ilerin \% $42,5^{\prime}$ 'in eğitimsiz, niteliksiz personelden oluştuğu ve işletmelerin $\% 36,9$ 'unda yabancı dil bilen personelin bulunmadığı tespit edilmiştir (Tablo 5, 6).

\subsection{Turizm Işletmelerinin Böğaziçi Bölgesi'ndeki Turizm Gelişmesine dair Algıları}

Yapılan değerlendirme ile turizm gelişmesmesinin söz konusu olduğu bölgede yer alan işletmelerin yere ait özellikleri nasıl 
Tablo 4. Olumlu ve olumsuz yargılara verilen cevapların skor cinsinden ifade edilmesi

\begin{tabular}{|c|c|c|c|c|c|c|}
\hline \multirow[t]{2}{*}{ Boyut } & \multirow[t]{2}{*}{ Boyuta ait ifadeler } & \multicolumn{5}{|c|}{ 5’li Likert Ölçeği } \\
\hline & & $\mathbf{I}$ & 2 & 3 & 4 & 5 \\
\hline & & $\begin{array}{c}\text { Kesinlikle } \\
\text { katılmıyorum }\end{array}$ & Katılmıyorum & $\begin{array}{c}\text { Ne katılıyorum } \\
\text { ne de katılmıyorum }\end{array}$ & Katılıyorum & $\begin{array}{c}\text { Kesinlikle } \\
\text { katılıyorum }\end{array}$ \\
\hline Yere bağılık turizmin & Olumlu ifade/ler & -3 & -2 & I & 2 & 3 \\
\hline algılanan etkileri & Olumsuz ifade/ler & 3 & 2 & I & -2 & -3 \\
\hline
\end{tabular}

Andereck \& Nyaupane, 2011, s. 252.

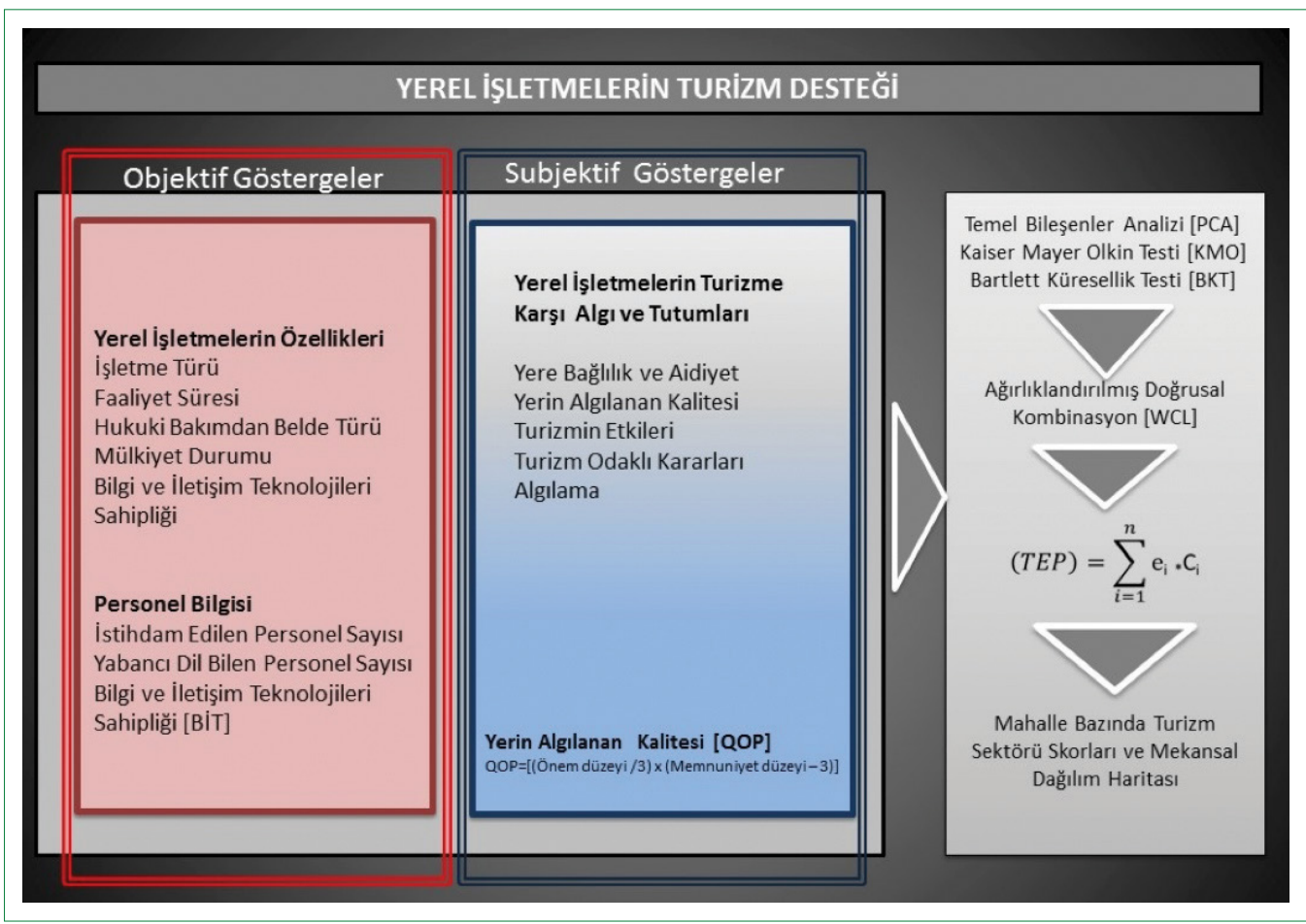

Şekil 3. Eğlence, yiyecek içecek işletmelerinin turizmin gelişmesi ile ilgili tavır ve tutumlarını ölçmek için geliştirilen yöntem.

algıladığını belirleyen skor değerleri elde edilmiştir. Negatif değerli skorlar işletmelerin yere dair hoşnutsuzluk düzeylerini, pozitif değerli skorlar işletmelerin yere dair hoşnutluk düzeylerini göstermektedir. Elde edilen verilere göre;

- İşletmelerin sosyal ve kültürel çevre özellikleri ile ilgili ifadelere verdikleri cevapların skorlarının ortalamasının 0,9830 ile 2,0482 arasında değişen skorlar aldığı görülmektedir. Elde edilen pozitif değerler işletmelerin Boğaziçi alanının sosyo kültürel çevresinden genel olarak hoşnut olduklarını ortaya koymaktadır.

- İşletmelerin ekonomik çevre özellikleri ile ilgili ifadelere verdikleri cevapların ortalamasının ise 0,6908 ile I,1759 arasında değişen skorlar aldığı görülmektedir. Elde edilen veriler işletmelerinin Boğaziçi alanının ekonomik çevre özelliklerinden de genel olarak hoşnut olduklarını göstermektedir.
- İşletmelerin Boğaziçi alanının fiziksel çevre özellikleri ile ilgili verilen ifadelere dair yaptığı değerlendirmenin ortalamalarının ise 3,1418 ile $-0,580 \mathrm{I}$ arasında değişen skorlar aldığı tespit edilmektedir.

İşletmelerin Boğaziçi alanının fiziksel çevresine dair hoşnutluklarını olumsuz yönde etkileyen başlıca etmenler:

- Otellerin varlığı (X:-I,45II; Std. sapma: I,49955); Beykoz ilçesindeki işletmelerin konaklama tesislerinin yetersizliğini ( $\bar{X}:-2,0238)$ diğer ilçelere göre görece daha fazla hissedildiği görülmektedir. Benzer bir şekilde Sarıyer ilçesindeki işletmelerinde $(\overline{\mathrm{X}}$ :- 1,6300$)$ konaklama tesislerinin varlı̆ı̆ı yeterli bulmadıklarını ifade ettikleri tespit edilmektedir.

- Otel işletmelerinin çeşitliliği ( $\overline{\mathrm{X}}:-1,4298 ;$ Std. sapma: I,52384); Beykoz ilçesindeki işletmelerin farklı faaliyet alanlarda faaliyet gösteren konaklama tesislerinin varlığını 


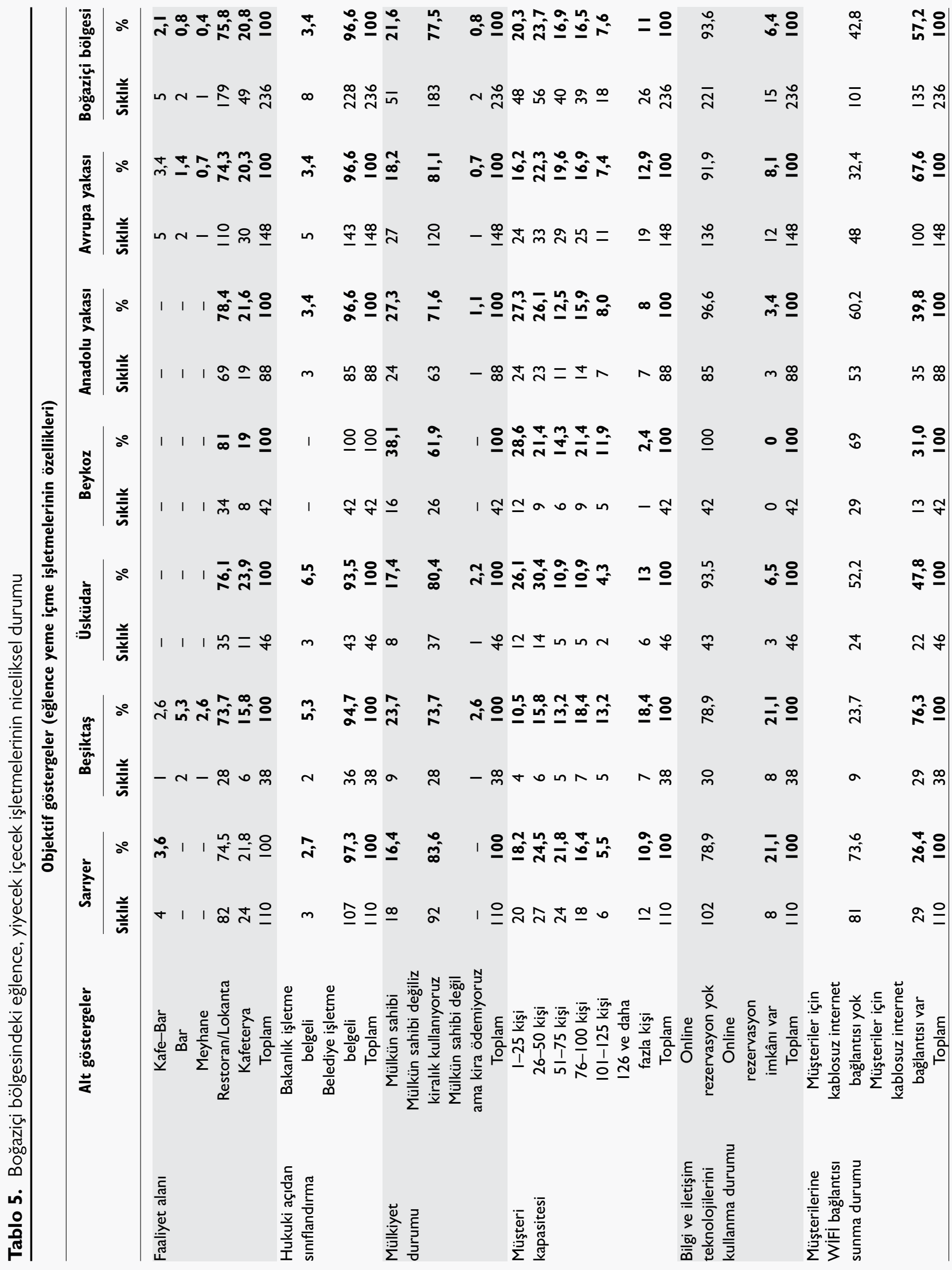




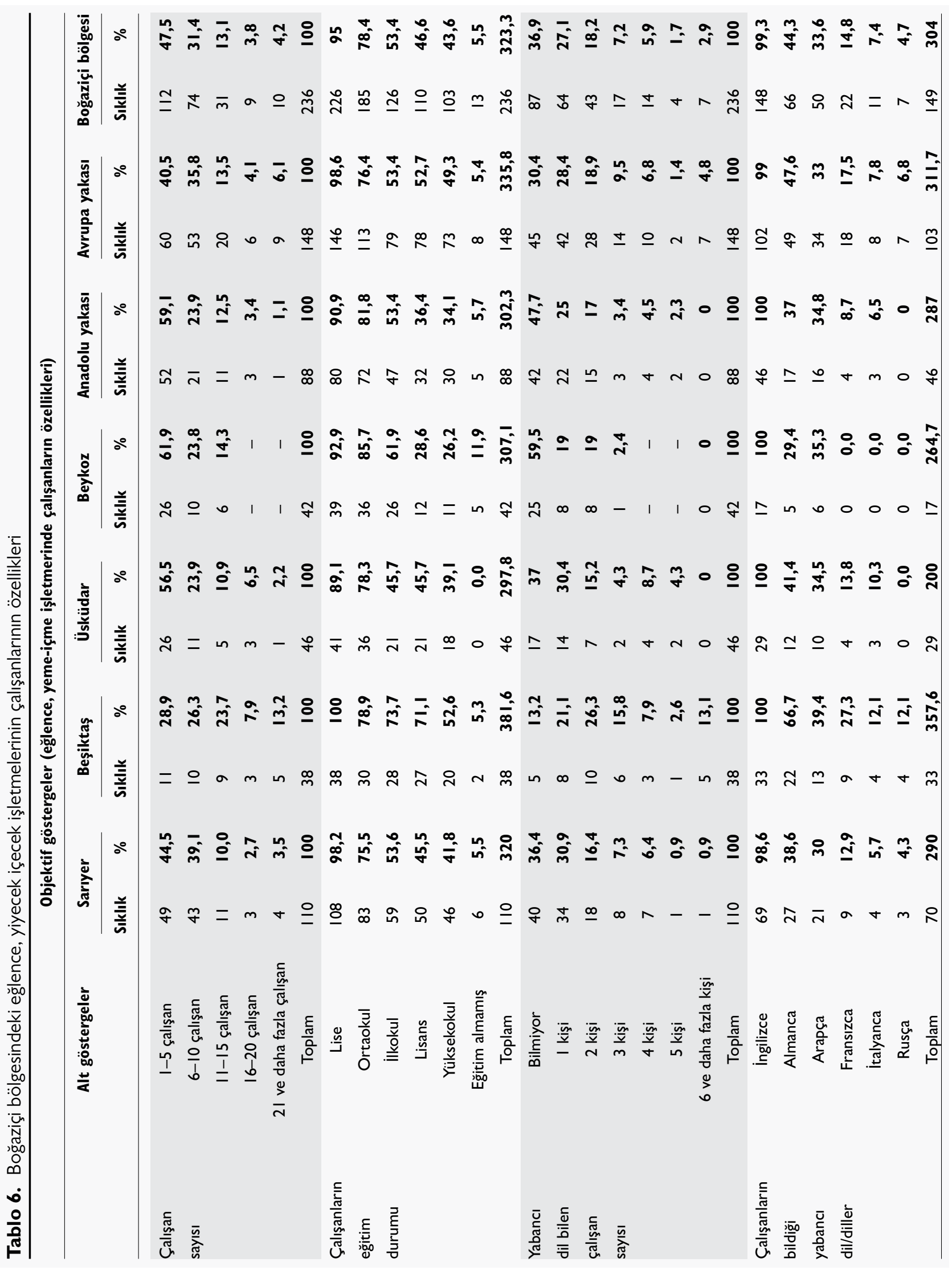


( $\overline{\mathrm{X}}:-2,0238)$ yeterli bulmadığını ortaya koymaktadır. Aryıca elde edilen bulgular Sarıyer ( $\overline{\mathrm{X}}:-1,584 \mathrm{I})$, Üsküdar ( $\overline{\mathrm{X}}$ :$\mathrm{I}, 5 \mathrm{I} \mid 45)$ ve Beşiktaş $(\overline{\mathrm{X}}:-0,228 \mathrm{I})$ ilçelerinde işletmelerinde farklı faaliyet alanlarında hizmet veren konaklama tesislerinin varlığına ihtiyaç olduğu görüşünde oldukları anlaşımaktadır.

- Otopark alanlarının varlığı (X):-0,763I; Std. sapma: I,27997); otopark alanlarının yetersizliğinin en fazla sırasıyla Beşiktaş ( $\overline{\mathrm{X}}:-0,9123)$, Sarıyer (X:-0,8073) ve Üsküdar ( $\overline{\mathrm{X}}:-0,7246)$ ilçelerinde hissedildiği anlaşılmaktadır.

- Deniz yolu ile ulaşım olanakları (X:-0,7319; Std. sapma: I,79836); deniz yolu ile ulaşım olananlarını yetersiz bulan işletmelerin sırasıyla Beykoz ( $\overline{\mathrm{X}}$ :- 1,8095$)$, Sarıyer $(\overline{\mathrm{X}}$ :$0,688 I)$ ve Beşiktaş ( $\bar{X}:-0,5088)$ ilçelerinde kümelendiği tespit edilmektedir.

- Kültürel mekanların varlığı (X:-0,580I; Std. sapma: I,327।2); kültürel mekanların yetersiz olduğunu ileri süren işletmelerin sırasıyla Beykoz ( $\overline{\mathrm{X}}$ :- 1,3889), Sarıyer ( $\overline{\mathrm{X}}$ :$0,6972$ ) ve Beşiktaş ( $\bar{X}:-0,0526)$ ilçelerinde kümelendiği belirlenmektedir.

Çalışma, merkezi ve yerel yönetimler tarafından geliştirilen turizm stratejilerine karşı hoşnutluğunu belirleyebilmek için verilen ifadelerin işletmelerin, sadece \% I0'una olumlu yönde cevap verdiklerini ortaya koymaktadır. İşletmelerin olumlu yönde görüş bildirdiği ifadelerin; merkezi ve yerel yönetimlerin kentsel kaliteyi arttırmak için yaptığı faaliyetler ( $\overline{\mathrm{X}}: \mathrm{I}, 1050$; Std. sapma: I,37I03) ile mevcut ve gelecekteki ihtiyaca cevap verebilmek için altyapıyı iyileştirmesi (X:I,I80I; Std. sapma: I,2427I) konusunda yaptıkları program ve faaliyetler olduğu görülmektedir. Ancak Boğaziçi alanındaki işletmelerin turizm stratejileri ile ilgili algılarını belirleyen diğer ifadelere verdiği cevapların ortalamasının $-0,3305$ ile $-1,346 \mid$ arasında değiştiği tespit edilmektedir. Boğaziçi alanındaki işletmelerin turizm stratejileri ile ilgili olumsuz yönde değerlendirdiği ilk beş ifadenin sırasıly;

- Nitelikli personel yetiştirilmesi için eğitim programlarının düzenlenmesi ( $\overline{\mathrm{X}}$ :- I,6950; Std. sapma: I,34826); elde edilen verilerden en fazla Beykoz ve Üsküdar ilçelerinde nitelikli personel ihtiyacı olduğu anlaşılmaktadır.

- Yabancı dil eğitimini teşvik etmek için ücretsiz yada düşük ücretli eğitim programlarının geliştirilmesi ( $\overline{\mathrm{X}}$ :- I,346I; Std. sapma: I,44357); sırasıyla Beykoz ( $\overline{\mathrm{X}}$ :- I,857I), Üskü$\operatorname{dar}(\overline{\mathrm{X}}:-1,5507)$ ve Sarıyer ( $\overline{\mathrm{X}}$ :- 1,3333$)$ ilçelerinde bulunan işletmelerin yabancı dil bilen nitelikli personel ihtiyacı olduğu belirlenmektedir.

- Turizm yatırımlarını teşvik etmek için vergi indirimleri $(\overline{\mathrm{X}}$ :0,9617; Std. sapma: I,05407); Beykoz ( $\overline{\mathrm{X}}:-1,2222)$ ve Üsküdar ( $\overline{\mathrm{X}}$ :- 1,0507$)$ ilçelerinde bulunan işletmelerin, Sarıyer $(\overline{\mathrm{X}}:-0,87 / 6)$ ve Beşiktaş $(\overline{\mathrm{X}}:-0,4737)$ ilçelerinde bulunan işletmelere göre turizm yatırımlarını teşvik etmek için vergi indirimlerine daha fazla ihtiyaç duydukları tespit edilmiştir.

- Yerel yönetimlerin karar ve uygulamalardan ilgilileri haber- dar etmesi ( $\overline{\mathrm{X}}$ :-0,8624; Std. sapma: I,00070); yerel yönetimlerin karar ve uygulamalardan haberdar olma konusunda Beykoz ( $\overline{\mathrm{X}}:-1,2222)$ ve Üsküdar $(\overline{\mathrm{X}}:-1,0507)$ ilçelerinde bulunan işletmelerin, Sarıyer ( $\overline{\mathrm{X}}$ :-0,8502) ve Beşiktaş $(\overline{\mathrm{X}}$ :0,5614 ) ilçelerinde bulunan işletmelere göre daha fazla hoşnutsuz oldukları belirlenmiştir.

- Uluslararası turizm acentaları ile güçlü bağlantıların geliştirilmesini desteklemesi ( $\overline{\mathrm{X}}: 0,8170$; Std. sapma: I,02258); Beykoz ilçesinde bulunan işletmelerin diğer ilçelerde bulunan işletmelere göre uluslararası turizm acentaları ile güçlü bağlar geliştirmekte karşılaştıkları kısıtlııkların daha fazla olduğu tespit edilmiştir.

Elde edilen tüm bu veriler turizm işletmelerinin destek ve danışmanlık hizmetlerini yetersiz buldunlarını ve turizm yatıımları teşvik mevzuatı ile birlikte mesleki eğitim destek ve danışmanlık hizmetlerine ihtiyaç duyduklarını ortaya koymaktadır.

\subsection{Eğlence, yeme-içme işletmelerinin turizm gelişmesine karşı davranış ve tutumlarını belirleyen faktörler ve önem düzeyi}

Boğaziçi Bölgesi'ndeki yerel işletmelerin turizm gelişmesine karşı davranış ve tutumlarını belirleyen faktörleri tespit etmek için yapılan PCA işleminde KMO değeri 0,855 ve Barlett's testi sonucu ise 19279,783 olarak bulunmuştur. 65 adet değişkenden oluşan yapının yedi faktörle açıklandığı görülmüştür. Yedi faktör için elde edilen toplam \%69,539'luk varyans oranı oldukça tatminkardır (Tablo 7) (Çokluk, Şekercioğlu, \& Büyüköztürk, 2010, s. 233).

İlk faktör; hükümet politikaları, hukuki yaptırım ve yasal düzenlemeler ve yerel yönetimlerin teşvikleri gibi unsurları içerdiği için "turizm odaklı stratejiler";

İkinci faktör, turizmin gelişmesi farklı kültürleri tanıma fırsatı sağlaması, turizmin gelişmesiyle kültürel ve sanatsal üretimin artması, turizmin gelişmesiyle yerel işletmelerin gelişmesi, turizmin gelişmesinin bölgeye daha fazla yatırım çekmesi gibi ifadeleri içerdiği için “turizmin algılanan olumlu etkileri”; Üçüncü faktör; satın alma fiyatlarının düşük olması, tedarikçilerin sayısı, tedarikçilerin çeşitliliği, iş gücünün kolay ve sürekli temini gibi ifadeleri içerdiği için "tamamlayıcı ve destekleyici çevresel koşullar" olarak kavramsallaştırılmışır.

Dördüncü faktör; yiyecek içeçecek işletmelerinin çeşitliliği, sosyal tesislerinin çeşitliliği, diğer turistik tesislere ve tedarikçilere yakınlık, tarihi ve kültürel çevre varlığı, eğlence mekanlarının varlığı gibi ifadeleri içerdiği için "sosyo ekonomik çevre koşulları"; Beşinci faktör; bu semti/bölgeyi benim bir parçam gibi hissediyorum; Bu mahallede çalışmaktan zevk alıyorum; semt ve insanlarına manevi bir bağımlılığımız var; alıştı̆̆ımız yer, uzun süredir işletmemiz burada gibi değişkenlerini içerdiği için "yere bağlılı"; 
Tablo 7. Eğlence, yiyecek içecek işletmelerinin turizm gelişmesine karşı tavır ve tutumunu belirleyen faktörler ve varyans oranları

\begin{tabular}{|c|c|c|c|c|}
\hline Turizm ile ilgili ifadeler & $\begin{array}{l}\text { Faktör } \\
\text { yükleri }\end{array}$ & $\begin{array}{l}\text { Cronbach's } \\
\text { Alpha }(\alpha)\end{array}$ & $\begin{array}{c}\text { Faktör } \\
\text { özdeğeri } \\
\text { oranı }\end{array}$ & $\begin{array}{c}\text { Açıklanan } \\
\text { varyans }\end{array}$ \\
\hline
\end{tabular}

\section{FI: Turizm odaklı stratejiler}

Ulusal turizm acentaları ile güçlü bağlantıların geliştirmesini desteklemesi

Tarihî, kültürel, sanatsal ve turistik değerlerini yurt içinde ve yurt dışında tanıtmak,

Tarihi çevre ve eski dokuya zarar vermeyecek ulaşım politikalarının geliştirmesi

Uluslararası turizm acentaları ile güçlü bağlantıların geliştirilmesini desteklemesi

Kültürel mirasın korunması için geliştirdiği politikalar

Tarihi yapıların restorasyonu için verdiği krediler

Tarihi çevrede yapılacak yeni yapıların çevreye aykırı olmalarını

önleyici karar ve yönetmelikler

Karar ve uygulamalarından ilgilileri haberdar etmesi

Turizm yatırımlarına yönelik diğer teşvik ve destekler

Turizm yatırımlarını teşvik etmek için vergi indirimleri

Turizmi geliştirmek için bilgi ve iletişim teknolojilerinin kullanımını desteklemesi

Geleneksel halk kültürlerini korumak ve yaşatmak için yaptığı araştırmalar

Yerel yönetimlerin karar ve uygulamalarından ilgilileri haberdar etmesi

Kültürel mirası koruma bilincini artırmak için düzenlediği eğitim programları

Tarihi ve kültürel alanlara yapılan yatırımlar

Açık alanlara ve parklara yapılan yatırımlar

Nitelikli personel yetiştirilmesi için eğitim programları düzenlemesi

Yabancı dil eğitimini teşvik etmek için ücretsiz/ düşük ücretli

eğitim programların geliştirilmesi

0,898

0,898

0,895

0,895

0,874

0,869

0,866

0,865

0,854

0,848

0,847

0,822

0,812

0,799

0,748

0,731

0,619

0,578

F2: Turizmin algılanan olumlu etkileri

Turizmin gelişmesi farklı kültürleri tanıma fırsatı sağlar.

Turizmin gelişmesi yerel kültürün önem kazanmasını sağlar.

Turizmin gelişmesiyle düzenlenen kültürel etkinliklerin sayısı artar.

Turizmin gelişmesiyle farklı kültürlere karşı övgü, takdir,

anlayış, saygı ve hoşgörü ortamı gelişir.

Turizmin gelişmesiyle kültürel ve sanatsal üretim artar.

Turizm gelişmesi tarihi yapıların özgünlüğünün korunarak kullanılmasını sağlar.

Turizmin gelişmesiyle yerel işletmeler gelişir.

Turizmin gelişmesiyle rekreasyonel olanaklar artar.

Turizmin gelişmesi bölgeye daha fazla yatırım çeker.

Turizmin gelişmesiyle yerel toplumun gelir düzeyi artar.

Turizmin gelişmesiyle iş olanakları artar.

Turizmin gelişmesiyle emlak değerleri artar.

0,502

F3: Tamamlayıcı ve destekleyici çevresel koşullar

Kültürel mekânların (sanat galerileri, müze, tiyatro vb.) varlığı

Tedarikçilere yakınlık

Tesisin ihtiyacı olan malzemeler için satın alma fiyatlarının düşük olması

Tedarikçilerin sayısı

0,919

Tedarikçilerin çeşitliliği

Bölgenin turistik değerinden dolayı kolay pazar bulma olanağı

Turistlerin yoğun olduğu merkezlere yakınlık

Bölgede nitelikli iş gücünün kolay ve sürekli temini
$0,969 \quad|2,47| \quad \% 19,186$

0,948

8,243

$\%|2,68|$
Kira değerleri 
Tablo 7 (devamı). Eğlence, yiyecek içecek işletmelerinin turizm gelişmesine karşı tavır ve tutumunu belirleyen faktörler ve varyans oranları

\begin{tabular}{|c|c|c|c|c|}
\hline Turizm ile ilgili ifadeler & $\begin{array}{l}\text { Faktör } \\
\text { yükleri }\end{array}$ & $\begin{array}{l}\text { Cronbach's } \\
\text { Alpha }(\alpha)\end{array}$ & $\begin{array}{c}\text { Faktör } \\
\text { özdeğeri } \\
\text { oranı }\end{array}$ & $\begin{array}{c}\text { Açılklanan } \\
\text { varyans }\end{array}$ \\
\hline
\end{tabular}

F4: Sosyo ekonomik çevre koşulları

Yeme-içme tesislerinin çeşitliliğ

Sosyal tesislerin çeşitliliği

0,783

Sosyal tesislerin varlı̆̆ı

0,783

Yeme-içme tesislerinin varlı̆̆ı

0,782

Yeme-iç̧me ve eğlence mekanları gibi diğer turistik tesislere yakınlık

0,777

0,943

5,041

$\% 7,755$

Park ve rekreasyon alanlarının varlı̆̆ı

0,682

$\begin{array}{ll}\text { Tarihi ve kültürel çevre varlığı } & 0,620\end{array}$

Gece kulüpleri, bar meyhane ve taverna gibi eğlence mekanlarının varlığı $\quad 0,595$

F5: Yere bağlılık

Bu semti/bölgeyi benim bir parçam gibi hissediyorum. $\quad 0,945$

Semt ve insanlarına manevi bir bağımlılı̆ımız var. $\quad 0,923$

$\begin{array}{lr}\text { Bu mahallede çalışmaktan zevk alıyorum. } & 0,905\end{array}$

0,893

$0,913 \quad 4,555 \quad \% 7,008$

Alıştığımız yer, uzun süredir buradayız.

0,762

daha olduğunu düşünmüyorum.

F6: Sosyo kültürel çevre koşulları

Halkın yabancılara karşı davranış ve tutumları

0,782

Halkın birbirlerine karşı davranış ve tutumları

0,768

İnsanların bilgisi ve görgüsü

0,757

0,943

4,260

$\% 6,554$

Geleneksel yaşam tarzı

0,736

İnsanların tarihi ve doğal çevreyi koruma bilinci

0,722

Sosyal ve kültürel hayatın canlılığı

0,679

F7: Turizmin olumsuz etkileri

Turizmin gelişmesiyle mahallenin huzuru azalır.

0,854

Turizmin gelişmesiyle doğal ve kültürel çevre tahrip olur.

0,804

Turizmin gelişmesiyle suç işleme oranları artar.

0,774

0,849

3,735

$\% 5,746$

Turizmin gelişmesi insanların yaşadıkları yerleri terk etmesine neden olur.

0,700

Turizm gelişmesi geleneksel kültürün yozlaşmasına neden olur.

0,675

Turizmin gelişmesiyle yerel halkın ahlaki değer

ve davranışları olumsuz yönde etkilenir.

0,658

$0,60 \leq \alpha<0,80$ ise ölçek oldukça güvenilirdir; $0,80 \leq \alpha<1,00$ ise ölçek yüksek derecede güvenilirdir.

Altıncı faktör, halkın yabancılara karşı davranış ve tutumu, geleneksel yaşam tarzı, insanların tarihi ve doğal çevreyi koruma bilinci, insanların bilgisi ve görgüsü, sosyal ve kültürel hayatın canlılığı güvenlik ve huzurun sağlanması gibi değişkenlerini içerdiği için "sosyo-kültürel çevre algısı"; Yedinci faktör, turizmin gelişmesiyle mahallenin huzuru azalır, turizmin gelişmesiyle doğal ve kültürel çevre tahrip olur, suç işleme oranları artar, geleneksel kültürün yozlaşmasına neden olur, soylulaştırma tehditi ve karşı karşıya kalınır gibi değişkenleri içerdiği için "turizmin algılanan olumsuz etkileri” olarak kavramsallaştırılmıştır. Yerel işletmelerin turizm gelişmesine karşı davranış ve tutumlarını belirlemede en çok etkiye sahip olan faktörlerin sırasıyla "turizm odaklı stratejiler", "turizmin algılanan olumlu etkileri”, "tamamlayıcı ve destekleyici çevresel” koşullar olduğu ortaya konulmuştur (Tablo 7).
İşletmelerin turizm gelişmesine karşı davranış ve tutumlarını belirleyen faktörlerin bütünleşik skorlarını ortaya koymak için yapılan WCL analizi sonuçları Tablo 8'de verilmiştir.

Elde edilen bulgular yerel işletmelerin \%53,84'ünün turizm gelişmesine karşı negatif yönde bir tutum sergiledikleri belirlenirken, \%46,16'sının ise böyle bir gelişmeye karşı pozitif yönde bir tutum sergilediklerini ortaya koymaktadır (Tablo 8; Şekil 4). Turizm gelişmesine karşı pozitif yönde davranış ve tutum ortaya koyan turizm işletmelerinin Beşiktaş ( $\mathrm{X}: 2,2262)$ ve Üsküdar ( $\overline{\mathrm{X}}: 0,082 \mathrm{I})$ ilçelerinde kümelendiği, ancak Beykoz

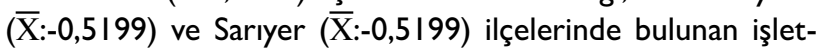
melerin çoğunluğunun ise turizm odaklı program ve faaliyetleri olumsuz yönde değerlendirdikleri anlaşılmaktadır. Başka bir 
Tablo 8. Eğlence, yiyecek içecek işletmelerinin turizm gelişmesine verdiği desteğin skor cinsinden ifadesi

\begin{tabular}{|c|c|c|c|c|c|c|}
\hline İlçe & Mahalle & $\mathbf{N}$ & Minimum & Maksimum & Ortalama & SS \\
\hline \multirow[t]{10}{*}{ Sarıyer } & Tarabya & II & $-5,02$ & $\mathrm{I}, 37$ & $-I, 5934$ & $2,|1| 36 \mid$ \\
\hline & Balta Limanı & 1 & $-1,02$ & $-1,02$ & $-1,0187$ & - \\
\hline & Emirgan & 8 & $-2,44$ & 4,42 & 1,1882 & 2,16652 \\
\hline & Rumeli Hisarı & 26 & $-6,10$ & $3,4 I$ & $-0,8457$ & 2,34275 \\
\hline & Rumeli Kavağı & 7 & $-0,79$ & 2 & 0,7391 & 0,95756 \\
\hline & Yeniköy & 15 & $-3,42$ & 6,57 & 2,3974 & 2,90403 \\
\hline & Büyükdere & 9 & $-9,11$ & 0,78 & $-3,3984$ & 3,43823 \\
\hline & Sarıyer merkez & 16 & $-4,22$ & 3,12 & $-1,0733$ & 2,54682 \\
\hline & İstinye & 16 & $-5,15$ & $\mathrm{I}, 80$ & $-I, 0733$ & $\mathrm{I}, 88530$ \\
\hline & Toplam & 109 & $-9,11$ & 6,57 & $-0,5199$ & 2,80194 \\
\hline \multirow[t]{5}{*}{ Beşiktaş } & Arnavutköy & II & $-4,41$ & 5,63 & 1,7377 & 3,38203 \\
\hline & Kuruçeşme & 8 & $-2,54$ & 5,24 & 2,5019 & 2,49779 \\
\hline & Ortaköy & 10 & $-2,09$ & 4,67 & I,7750 & 2,31935 \\
\hline & Bebek & 9 & $-1,26$ & 6,90 & 3,0796 & 2,80486 \\
\hline & Toplam & 38 & $-434 I$ & 6,90 & 2,2262 & 2,75696 \\
\hline \multirow[t]{6}{*}{ Üsküdar } & Beylerbeyi & 10 & $-2,29$ & 4,68 & 0,9899 & 2,02282 \\
\hline & Sultantepe & 9 & $-1,38$ & 2,42 & 0,2828 & 1,35222 \\
\hline & Kuzguncuk & II & $-2,33$ & 3,79 & 0,4897 & $\mathrm{I}, 93344$ \\
\hline & Çengelköy & 12 & $-4,13$ & 6,41 & $-0,9716$ & 3,09612 \\
\hline & Kandilli & 4 & $-1,24$ & 0,02 & $-0,5983$ & 0,58304 \\
\hline & Toplam & 46 & $-4,13$ & 6,91 & $0,082 I$ & 2,21564 \\
\hline \multirow[t]{9}{*}{ Beykoz } & Göksu & 2 & $\mathrm{I}, 83$ & 2,73 & 2,2832 & 0,63783 \\
\hline & Anadolu Hisarı & 6 & $-3,67$ & $-0,24$ & $-1,6993$ & 1,61172 \\
\hline & Anadolu Kavağı & 7 & $-3,90$ & 2,31 & $-0,9022$ & 2,45593 \\
\hline & Yalıköy & 2 & $-6,68$ & $-3,91$ & $-5,2963$ & 1,96386 \\
\hline & Paşabahçe & 7 & $-0,95$ & $2,4 I$ & $-0,3467$ & $\mathrm{I}, 74434$ \\
\hline & Çubuklu & 10 & $-5,46$ & 0,59 & $-2,0359$ & I,7IIOI \\
\hline & Beykoz merkez & 3 & $-1,60$ & 0,90 & $-0,3456$ & $\mathrm{I}, 25255$ \\
\hline & Kanlıca & 6 & 0,46 & 4,40 & 1,48698 & $\mathrm{I}, 48698$ \\
\hline & Toplam & 42 & $-6,68$ & 4,40 & $-0,7550$ & 2,80194 \\
\hline
\end{tabular}

SS: Standart sapma.

ifadeyle Sarıyer ilçesindeki eğlence yeme içme işletmelerinin \%67,67'sinin, Beykoz ilçesindeki eğlence yeme içme işletmelerinin \%75'inin ve Üsküdar ilçesindeki eğlence yeme içme işletmelerin \%40'ının turizm gelişmesini negatif yönde değerlendirdikleri, bunun tam aksine Beşiktaş ilçesindeki eğlence yeme içme işletmelerinin ise, tamamının turizm gelişmesini pozitif yönde değerlendirdikleri anlaşılmaktadır (Tablo 8; Şekil 4).

Turizm gelişmesini olumlu yönde değerlendiren eğlence yeme içme tesislerinin Bebek $(3,08)$, Kuruçeşme $(2,50)$, Yeniköy $(2,39)$, Göksu $(2,28)$, Ortaköy $(1,77)$, Arnavutköy $(1,74)$, Kanlıca $(I, 48)$ ve Emirgan $(I, I 882)$, mahalleleri olduğu belirlenmiştir. Bu mahalleler üst gelir gruplarının konut alanlarının ve yeme-içme, eğlenceye yönelik aktivitelerin daha yaygın olduğu, öteden beri kentin tarihi merkezi ile 19. yüzyılda konan tramvay hatları ve vapur seferleri nedeniyle ilişkilerinin daha güçlü olduğu yabancı misyonların ikamet ettiği alanlardır.
Turizm gelişmesine karşı en fazla negatif tutum sergileyen ilk beş işletmenin sırasıyla Yalıköy $(-5,296)$, Büyükdere $(-3,3984)$, Çubuklu $(-2,0359)$, Anadolu Hisarı $(-1,6993)$ ve Tarabya $(-1,5934)$ mahallelerinde bulunduğu görülmüştür. Bu gruptaki mahallelerden Yalıköy, Anadolu Kavağı, Çubuklu ve Anadolu Hisarı İstanbul'da ilk sanayi hareketlerinin başladığı Beykoz (kağıt fabrikası, şişe cam fabrikası)'da konumlanmaktadır. Bu mahalleler genellikle düşük gelir gruplarının yer seçtiği, modern mülkiyet sisteminin dışında gelişen gecekondu ve ruhsatsız yapılaşma şeklinde oluşan kaçak kent parçalarından oluşmaktadır. Dolayısıyla bu bölgelerdeki eğlence, yeme içme işletmeleri rekabet gücü zayıf küçük ölçekli işletmelerden oluşmaktadır (Beykoz'daki işletmelerin \%6l'i I-5 çalışanlıdır). Ayrıca bu mahallelerde yaşayanlar yoksulluk sınırında ya da altında yaşayan işgücünden oluşmaktadır. Bu noktada bu mahallelerdeki yerel işletmelerin asıl endişesi, turizmin gelişmesi için ulusal ve uluslararası turisti hedef alan girişimcilerin daha 


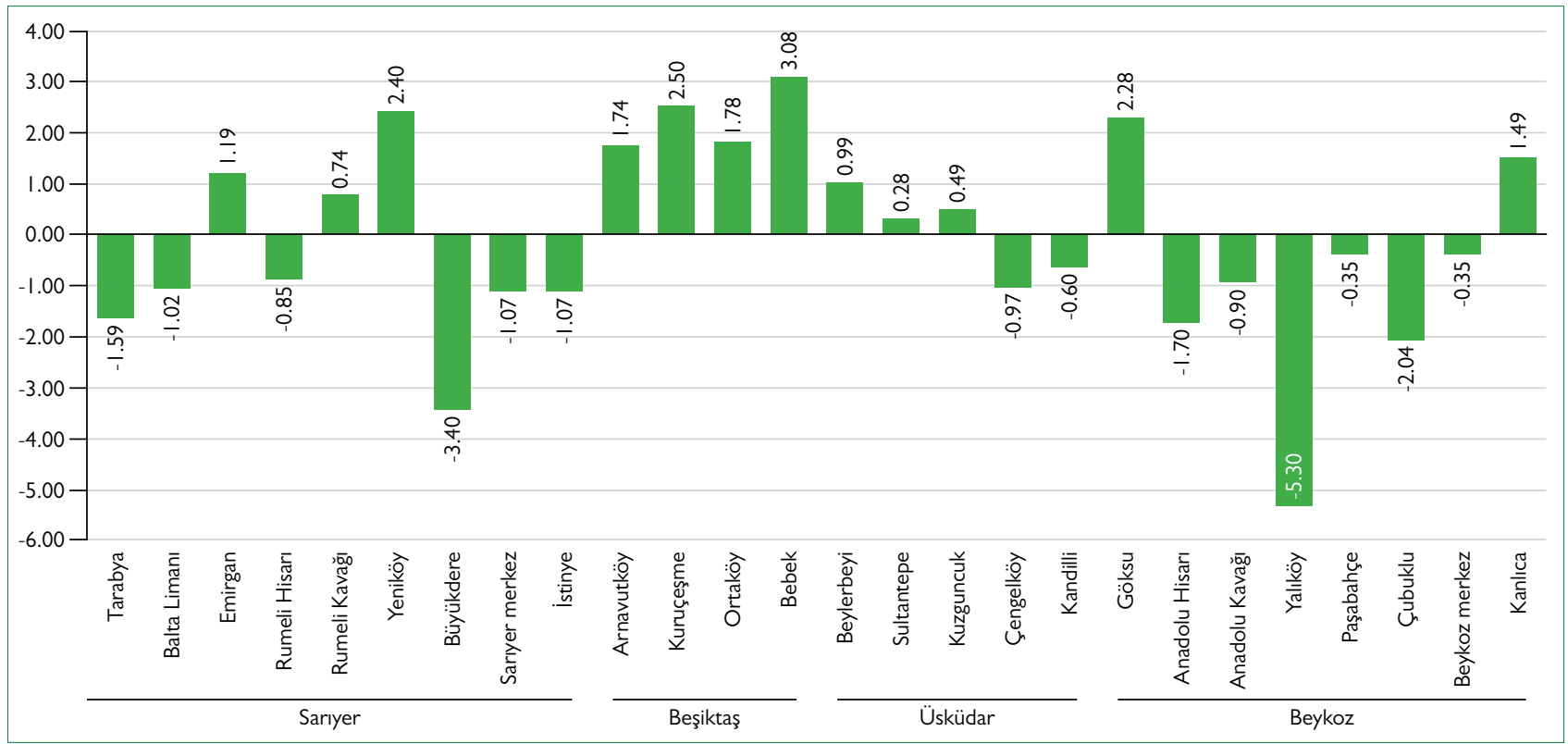

Şekil 4. Eğlence, yiyecek ıçecek işletmelerinin turizm gelişmesine verdiği desteğin mekansal olarak dağılımı.

varlıklı kesimler ve turistler için mekanlar üretmesiyle birlikte, mahallenin kendi sakinlerinin artan yaşam maliyetlerini karşılayamayarak yerinden edilmesidir. Çünkü bu süreç sonunda yerel işletmeler asıl müşterilerini kaybedecektir. Soylulaştırma süreci diyebileceğimiz bu süreçler Anadolu Yakası'ndaki Kuzguncuk, Avrupa Yakası'ndaki Ortaköy ve Arnavutköy mahallelerinde daha çok bireysel girişimlerle şekillenerek yaşanmıştır. Günümüzde Ortaköy kahveler, gece kulüpleri, barlar, lokantalar, sanat atölyeleri, antika ve hediyelik eşya dükkanları ve elişi ve sanat pazarıyla, yerli ve yabancı turistlerin buluşma merkezi haline gelmiş ve bu şekilde mahalle giderek varlıklı kesimlerin yaşayabileceği bir kent mekanı haline gelmiştir (Uğur, 1993). Bu nedenle küçük ölçekli eğlence yeme içme işletmeleri organize şekilde yapılacak olan turizm ve ticari odaklı projeler ile birlikte asıl müşterileri olan dar gelirli gruplar ile orta gelirli grupların yerinden edileceğini ve bu durumun mahallenin sosyal karakteri tamamen değişene kadar devam edeceğini düşünerek endişelenmektedir.

\section{Tartışma ve Sonuç}

Son yıllarda şehir yönetimleri işletmecilikten girişimciliğe zorlanan bir kayma yaşamaya başlamışlardır. Daha önceki yıllarda kentsel yönetişim, öncelikli olarak yerel hizmet ve tesislerin sağlanmasına odaklanmış olsa da, günümüzde yerel kalkınmayı desteklemek, teşvik etmek ve bunun yanı sıra ulusal ve uluslararası düzeydeki kaynakları çekmek için yeni yollar bulabilme konusuyla giderek daha fazla ilgilenmeye başlamıştır. Başka bir ifadeyle, doksanlı yıllardan itibaren devlet ve hükümetin kentsel politikalardaki rolü sağlayıcıdan çok uyarıcılığa evrilmiştir. Bu bağlamda, merkezi ve yerel yönetimler küresel turizm akışını ve yerel kalkınmayı teşvik eden yatırımları çekmek için, kentsel imajlarının pazarlanması ve/veya yeniden inşaasını bir araç olarak görmeye başlamıştır. Turizmde rekabetçiliği arttırmaya yönelik olan bu argümanlar kollektif tüketim, sosyal hizmetler ve gelirlerin yeniden dağıtılmasından ziyade ekonomik büyüme ve kalkınmaya odaklanan bir söylem ve yaklaşımı desteklemektedir. Turizmin bölgesel istihdam ve gelir dağılımı üzerinde etkisi tabi ki yadsınamaz. Ancak turizmin negatif ve kaçınılmaz etkilerini gözardı etmek doğru bir tutum değildir. Turizmle ilgili birçok çalışmada turizmin gelişim süreci analiz edilirken, genellikle ekonomik sermaye göz önünde bulundurulmuştur. Araştırma sorusuna bağlı olarak, turizmin arsa değeri üzerine etkisinin değerlendirilmesi, turizm sayesinde elde edilen gelirler ve iş olanakları, ticari binalara (commercial building), evlere ya da iş için yapılan yatırımlar, kira bedellerinin incelenmesi, gibi turizmin ekonomik etkileri üzerinde durulmuştur. Bu etkilerin analizlerinin yapılması da gereklidir. Ancak turizm gelişmesinin sosyal, kültürel ve çevresel unsurlara olan etkilerinin belirlenmesine yönelik daha kapsamlı bir analiz sürecine ihtiyaç duyulmaktadır. Böyle bir değerlendirmeyi yapabilmek için öncelikle farklı temsil ve uzmanlık alanlarından kentlilerin katılımıyla, bir kentin dinamiklerinden kaynaklanan temel meseleler tespit edilmelidir. Başka bir ifadeyle, kentteki turizm altyapısının mevcut durumundan, kent içi hedefleri belirleyebilme aşamasına geçebilmek için, sorun ve çözüm önerilerini ortaya koymak gereklidir. Çünkü paydaşlar ile kentin turizm açısından dinamiklerinin tartışılması ve sonuçların birarada değerlendirilmesi sonrasında saptanan sorunlar, kent ölçeğinde yönelimin arka planını görmek ve gerekçelerimizi belirlemek açısından da oldukça önemlidir. Bu nedenle bu çalışmada, turizm gelişmesini etkileyen ve turizm gelişmesinden etkilenen paydaşların turizm gelişmesine dair davranış ve tutumlarını belirleyen çevresel koşullara dair unsurları nasıl 
değerlendirdiklerini ortaya koyabilmek için bir araştırma yöntemi önerilmiştir. Önerilen yöntem, bölgede gerçekleştirilen turizm faaliyetlerinin ne kadar doğru olduğu, hedeflere ne kadar yaklaştığı, hedeflere ulaşmadaki engellerin tanımlanması ve giderilmesi için ne tür çalışmalar yapılması gerektiği konusunda araştırmacılara önemli ipuçları sağlamaktadır.

Araştırmaya göre bölgede hizmet veren eğlence ve yeme içme işletmelerinin turizm gelişmesine karşı davranış ve tutumlarını belirleyen faktörler sırasıyla; turizm odaklı stratejiler, turizmin algılanan olumlu etkileri, tamamlayıcı ve destekleyici çevresel koşullar, ekonomik çevre koşulları, yere bağıılık, sosyo-kültürel çevre koşulları ve turizmin algılanan olumsuz etkileri olarak belirlenmiştir. Yapılan analizlere göre işletmeler açısından turizm gelişmesine karşı davranış ve tutumu belirleyen en önemli faktörün turizm odaklı stratejiler olduğu tespit edilmiştir. Bu durum sürdürülebilir bir kentsel gelişme için kentlileri ve yere özgü değerleri gözeten kamu politikalarına ihtiyaç olduğunu ortaya koymaktadır. Ek olarak elde edilen veriler, işletmelerin Boğaziçi Bölgesi'nin sosyal, kültürel ve ekonomik çevre ile ilgili özelliklerinden genel olarak hoşnut olduklarını ortaya koymaktadır. Ancak işletmeler kültürel mekanların yetersizliği, deniz yolu ile ulaşım olanaklarının kısıtlılı̆̆ı, otopark alanlarının yetersizliği gibi konulardan duydukları rahatsızlığı da belirtmiştir. Yine elde edilen bulgular, turizm odaklı gelişmeye dair davranış ve tutumların pozitif yönde olduğu tespit edilen işletmelerin çoğunluğunun merkezi konumdaki Beşiktaş ilçesinde bulunduğu göstermektedir. Beykoz, Sarıyer ve Üsküdar ilçelerinde bulunan işletmelerin ise böyle bir gelişmenin olumsuz etkilerini daha fazla hissettiklerini ortaya koymaktadır. Yapılan incelemede turizm gelişmesinin olumsuz etkilerini diğerlerine göre görece daha fazla hisseden eğlence ve yeme içme işletmelerinin kümelendiği mahallelerin, genellikle düşük gelir gruplarının yaşadığı gecekondu alanları olduğu anlaşılmaktadır. Dolayısıyla bu mahallelerdeki yerel işletmeler de rekabet gücü zayıf küçük ölçekli işletmelerden oluşmaktadır. Bu noktada bu mahallelerdeki yerel işletmelerin iki temel endişesinden bahsetmek mümkündür: Birincisi turizmin gelişmesi için ulusal ve uluslararası turisti hedef alan girişimcilerin daha varlıklı kesimler ve turistler için mekanlar üretmesiyle birlikte, mahallenin kendi sakinlerinin artan yaşam maliyetlerini karşılayamayarak yerinden edilmesidir. Bunun bir sonucu olarak yerel işletmeler de asıl müşterilerini kaybedeceklerdir. İkincisi yeni müşteri potansiyelinin tüketim alışkanlıklarına yanıt verebilecek bir atmosfere de finansal nedenlerle uyum sağlayamayacak olmaları ve meydana gelen keskin rekabet ortamında artan maliyetleri karşılayamayacak duruma gelerek yerinden edilebileceklerini düşünmeleridir. Bu nedenle, Boğaziçi alanında, kitlesel turizmi alevlendirmeyen, bölgenin sosyal ve ekonomik eşitsizliklerini giderecek, yerel düzeyde turizm gelişmesinde rol alan aktörler ile yerin sakinleri ve küçük ölçekli işletmelerin çıkarlarını çabalarının merkezine yerleştirecek ve turizm faaliyetlerinin kurumsal ve düzenleyici bir bağlam içerisinde ele alınmasını sağlayacak bir turizm anlayışının benimsemesi gerekmektedir. Başka bir ifadeyle, turizmin Boğaziçi alanında emlak ve kira fiyatlarını arttırıcı ve bu bölgelere kimliğini veren asli unsurları yerinden edici etkilerini önleyecek tedbirler alınmalıdır.

Araştırma da Boğaziçi alanındaki eğlence ve yeme içme işletmelerini kısıtlayan etmenler; yeterli ve nitelikli personel eksikliği, teknolojik olanaklardan yeterince faydalanamamak, tüketici tercihlerindeki değişimi yakalayamamak, tedarikçilerden mal ve hizmet alımının fiyatlarının yüksek olması, otellerin, eğlence, yiyecek ve içecek işletmelerinin hizmet çeşitliliğinin kısıtlı olması, işletmeler ile ilgili satış gücünü artırmak için satış ve pazarlama yöntemi belirlenmemesi, interneti aktif kullanmamak, teşvik ve desteklerden haberdar olmamak ve kurumsallaşamamak olarak tespit edilmiştir. Planlama aşamasında bu kısıtlar göz önüne alınarak işletme performanslarını arttıracak stratejiler geliştirilmelidir. Aryıca Boğaziçi bölgesinde yapılacak turizm yatırımlarının tarihi doku ile kolaylıkla bütünleşebilen ve hatta bu yapı stoğunun değerlendirmesi açısından önemli fırsatlar sunan küçük ölçekli, nitelikli işletmelerin kapasitesini arttıracak biçimde yönlendirilmesine ihtiyaç olduğu düşünülmektedir. Bu amaçla küçük ve orta ölçekli sermayedarları desteklemek ve yerin sakinlerine meslek edindirme eğitimleri vermek gibi faaliyet ve programların ticari ve konutsal soylulaştırmanın önüne geçebilecek daha dengeli koşulların temini içinde yararlı olabilir. Ek olarak turizmin olumsuz etkilerini azaltmak için yerin sakinleri, turizm girişimcileri ve çalışanların koruma kültürünü oluşturacak eğitimlere de yer verilmelidir.

Yapılan saha çalışması eğlence, yeme içme sektörlerinin temsilcilerinin turizm altyapısını oluşturan müzeler, galeriler, tiyatrolar gibi kültürel işlevleri yeterli bulmadıklarını ortaya koymaktadır. Bu sonuç bizlere çağdaş kültür ve sanat üretiminin desteklenmesi gerektiğini göstermektedir. Unutmamak gerekir ki bir yandan kültür mirasının tüm katmanlarıyla ve titizlikle korunmuş, öte yandan çağdaş kültür ve sanat ile bütünleştirilmiş bir kent, nitelikli kültür turistlerini çekmesinin yanı sıra kentliler içinde kentsel yaşam ve çevre kalitesi yüksek yerler olacaklardır.

Sonuç olarak Boğaziçi alanında dinlence ve eğlenceye odaklanan bir yaklaşımın ekonomik büyümeyi desteklemeye katkıda bulunabileceği söylevleri yerel yönetimler tarafından kabul görebilir ancak bu tür politika ve müdahalelerin, kent kullanıcıları, turistler ve kentin geçici sakinlerine odaklanma eğiliminde olduğu unutulmamalıdır. Bu tür stratejiler ile eğlence ve yeme içme işletmeleri belirli alanlarda yoğunlaşmakta ve bu dönüşümlerin maliyet ve faydaları hem mekânsal hemde sosyal açıdan eşit olarak dağıtılmamaktadır. Aslında mahallelerin ve kentsel alanların dinlence ve tüketim yerleri olarak ortaya çıkmasının, genellikle ticari ve konutsal bir soylulaştırma ve yer değiştirme sürecini de tetiklediği de bilinmektedir. Ancak turizm planlaması konusunda çalışanlar yalnızca 
kentsel alanların maddi ve ekonomik olarak geliştirilmesine özen gösterdiği sürece, bu süreçlerin sosyal sonuçları gözardı edilmeye devam edilecektir. Bu durumu iyileştirmek için sosyal doku ve maddi arazi kullanımı arasındaki bağlantı gözönünde bulundurularak, turizm gelişme süreçlerinin orada yaşayan ve çalışanları olumsuz yönde etkileyebileceği gerçeğinin kabul edilmesi gerektiğidir. Yerel idarelerin mevcut yaklaşımı aslında neoliberal bir ideolojinin ve rekabetçi ve girişimci bir kent modelinin onaylanmasına paralellik göstermektedir. Bu tür bir yaklaşımda kentsel mekanda ekonomik gelişme odaklı belirli kullanımlar ile birlikte belirli faaliyetler memnuniyetle karşılanırken, sosyal doku ile ilgili boyutların ciddiye alınmadığı görülmektedir. Başka bir ifadeyle, dinlence ve eğlence işletmelerinin açılması yerel makamlar tarafından teşvik edilmese de memnuniyetle karşılanabilmekte, yan etkileri ise göz önünde bulundurulmamaktadır. Dolayısıyla kentsel metalaşma ve iyileştirme süreçleri ile ilgili eşitlik ve sosyal adalet meseleleri merkezi ve yerel yönetim çalışanları ve girişimciler tarafından da büyük ölçüde gözardı edilmektedir. Oysaki turizm gelişmesi için iç içe geçmiş sosyal, ekonomik ve yapısal unsurların birlikte çözülmesi gerektiği düşünüldüğünde turizmin turistik bölge üzerindeki çok boyutlu etkilerinin mutlaka ele alınması gerektiği açıcça görülmektedir. Sonuç olarak yerli ve yabancı girişimcileri Boğaziçi Bölgesine çekmek üzere yapılan müdahalelerin mahallelerin sosyal, kültürel ve fiziki dokusunda bir değişim meydana getireceği ve bu değişimin mahallenin özgün kimliğinin de değişmesine neden olan bir soylulaşma sürecini tetikleyebileceği unutulmamalıdır.

\section{Teşekkür}

Bu çalışma, Yıldız Teknik Üniversitesi Bilimsel Araştırma Projeleri Koordinatörlüğü’ nün 20130302DOPOI numaraIı projesi ile desteklenmiştir. Bilimsel Araştırma Projeleri Koordinatörlüğü'ne çalışmanın seyri boyunca sunmuş olduğu maddi katkılar için teşekkür ederiz.

\section{KAYNAKLAR}

Andereck, K. L., \& Nyaupane, G. P. (2011). Exploring the Nature of Tourism and Quality of Life Perceptions among Residents. Journal of Travel Research, 50: 248-260.

Aydıner Boylu, A., \& Terzioğlu, G. (2007). Ailelerin Yaşam Kalitelerini Etkileyen Bazı Objektif ve Subjektif Göstergelerin İncelenmesi. BAP, Hacettepe Üniversitesi Bilimsel Araştırmalar Birimi, Ankara. 02 11, 2018 tarihinde https://ailetoplum.aile.gov.tr/uploads/pages/bilim-serisi/46ailelerin-yasam-kalitelerini-etkileyen-bazi-objektif-ve-subjektifgostergelerinin-incelenmesi.pdf adresinden alındı

Bahar, O. (2004). Türkiyéde Turizm Sektörünün Rekabet Gücü Analizi Üzerine Bir Alan Araştırması: Muğla Örneği. Muğla: Yayınlanmamış Doktora Tezi, Muğla Üniversitesi Sosyal Bilimler Enstitüsü.

Beşiktaş Belediyesi. (2014). Beşiktaş่ta yaşam rehberi. www.besiktas.bel.tr.

Beykoz Belediyesi. (2014). Beykoz'daki Yeme-İçme Yerleri, Beykoz Belediyesi Ruhsat ve Denetim Müdürlüğü Verisi.

BİM. (2008). Boğaziçi Sahil Şeridi ve Öngörünüm Bölgesi Uygulama İmar Plan Raporu. İstanbul.

Bolzoni, M. (2013). What tourists ignore Ambivalences, conflicts and compromises in a changing neighbourhood. RC21 Conference 2013, Session 17: Resistance and Protest in the Tourist City. http://www.rc21.org/conferences/berlin2013/prog-17.php. adresinden alındı

Bolzoni, M. (2014, 24 June). Turning tp Leisure and entertainment in times of crisis. Atlantıs Magazıne, s. 24(4): 10-13.

ÇDP. (2009). 1/100000 ölçekli İstanbul Çevre Düzeni Planı Şehir Planlama Müdürlüğü. İstanbul: İstanbul Büyük Şehir Belediyesi İmar ve Şehircilik Daire Başkanlığı.

Çokluk, Ö., Şekercioğlu, G., \& Büyüköztürk, Ş. (2010). Sosyal Bilimler için Çok Değişkenli İstatistik SPSS ve LISTER Uygulamaları. Ankara: Pegem.

Doğan, H. Z. (2004). Turizmin Sosyo-Kültürel Temelleri. Ankara: Detay Yayıncilik.

Dwyer, L., \& Kim, C. (2003). DestinationCompetitiveness: Determinants and Indicators. Current Issues in Tourism 6(5):, 369-414.

Grodach, C., \& Loukaitou-Sideris, A. (2007). Cultural Development Strategies and Urban Revitalization., (s. 13(4): 349-370).

Hall, T. (1998). Urban Geography. London: Routledge. doi:ISBN 0-41514084-6,

Huning, S., \& Novy, J. (2006). Tourism as an Engine of Neighborhood Regeneration? Some Remarks Towards a Better Understanding of Urban tourism beyond the 'Beaten Path. CMS Working Paper Series| No. 0062006. 09 18, 2014 tarihinde http://www.geschundkunstgesch.tu-berlin. de/uploads/media/006-2006_03.pdf, adresinden alındı

Kuntay, O. (2004). Sürdürülebilir Turizm Planlaması. Ankara: Alp Yayınevi.

Mommaas, H. (2004). Cultural Clusters and the Post-industrial City: Towards The Remapping of Urban Cultural Policy. Urban Studies, 41 (3): 507-532.

Öncü, A. (2005). İdealinizdeki Ev Mitolojisi Küresel Sınırları Asarak İstanbul'a Ulaştı", Mekan, Kültür, İktidar: Küreselleşen Kentlerde Yeni Kimlikler. A. Öncü, \& P. Weyland. içinde İstanbul: İletişim Yayınları.

Özer, S. U. (2010). Şehir Turizmi ve Kültür: Yabancı Turistlerin Kültürel Bir Destinasyon Olarak İstanbul'u Değerlendirmeleri Üzerine Bir Araştırma. Eskişehir, Türkiye: Anadolu Üniversitesi Turizm ve Otel İşletmeciliği Anabilim Dal.

Peck, J. (2005). Struggling With The Creative Class. International Journal of Urban and Regional Research, Blackwell, 29(4): 740-770.

Raphael, D., Brown, I. D., Renwick, R., Cava, M., Weir, N., \& Heatcote, K. (1998). How to Carry Out a Community Quality of Life Project. A Manual. Department of Public Health Sciences, Toronto. Journal of Envi- 
ronmental Psychology, 30:422-434.

Ritchie, J., \& Crouch, G. (2000). The Competitive Destination: a Sustainability Perspective. Tourism Management 21(1): 1-7.

Sarıyer Belediyesi. (2014, 10 24). Sarıyer İlçesindeki Yeme İçme Yerleri, Sarıyer Belediyesi Ruhsat ve Denetim Müdürlüğü Verisi.

Uğur, S. (1993, 08 01). Bir Zamanlar Ortaköy. https://core.ac.uk/download/ pdf/38303127.pdf adresinden alınd 1

Üsküdar Belediyesi. (2014, 24 10). Üsküdar İlçesindeki Yeme İçme Yerleri, Üsküdar Belediyesi Ruhsat ve Denetim Müdürlüğü Verisi, Sarıer 24.10.2013. 2013.

Wilson, D., \& Keil, R. (2008). The real creative class. Social \& Cultural Geography,, 9: 8, 841-847.

Yılmaz Çakmak, B. (2013). Kültürel mirasın korunması bağlamında bir yeniden kullanım örneği, Hamdi Gültepe Evi. Artium Dergisi,, 1(1): 54-64.

Yoon, Y. (2002, September 19). Development of Structural Model for Tourism Destination Competitiveness from Stakejolders' Perspective. Blacksburg, Virginia, USA: Doctor of Philosophy in Hospitality and Tourism Management, Virginia Polytechnic Institute and State University. 